\title{
Muhasebe Ĕğitimi Alan Öğrencilerin Muhasebe Algılarına Yönelik Metaforlar
}

\author{
Sema AKPINAR* \\ Şule YILDIZ **
}

\section{ÖZET}

Çalışmanın amacı, muhasebe eğitimi alan ögrencilerin muhasebe kavramına yönelik algllarını renk, hayvan, besin türü, mevsim, oyun, çiçek ve eşya metaforları aracıllğıyla incelemektir. Bu amaç doğrultusunda, 2015-2016 ögretim yllında Sakarya Üniversitesi Işletme ve Siyasal Bilgiler Fakültelerinde İșletme, Sağllk Yönetimi, Finansal Ekonometri ve Yönetim Bilișim Sistemleri bölümlerinde öğrenim gören ve genel muhasebe dersini alan toplam 271 ögrenciden "Ĕ̆er muhasebe bir renk (hayvan, besin türü, mevsim, oyun, çiçek ve eşya) olsaydl, “....” olurdu. Çünkü “....” cümlelerini tamamlamalar istenmiştir. Verilerin analizinde frekans, yüzde hesaplamaları ve içerik analizi yöntemi kullanılmıştır. Elde edilen verilerin nitel analizi sonucu muhasebe eğitimi alan öğrencilerin muhasebe kavramına ilişkin algıları arasında "zor, slkıcı ve karmaşık bir ders olarak muhasebe", "gerekli, faydall, önemli bir ders olarak muhasebe" ve "heyecan verici bir ders olarak muhasebe" algılarının ön plana çıktı̆̆ görülmektedir. Araştırmaya katılan ögrencilerin her bir kategori için en yaygın olarak kullandikları metaforlar sırayla "siyah, aslan (kaplan), sebze türü, kış, saklambaç, kaktüs ve hesap makinesi” dir.

Anahtar Kelimeler: Muhasebe Eğitimi, Metafor, Muhasebe Algısı.

JEL Siniflandirmast: M00, M40, M41.

\section{Metaph
Education}

ABSTRACT

Purpose of the study, to examine accounting students' perceptions of accounting concept /course through color, animal, food type, season, game, flower and ware metaphors. In accordance with this purpose, 271 students in total who have attended general accounting course in 2015-2016 academic year in Sakarya University Faculty of Business and Political Sciences in Business Administration, Health Management, Financial Econometrics and Management Information Systems departments are asked to complete the sentences: "If accounting had a color (animal, food type, season, game, flower, and ware), it would be ...... ". In the analysis of the data, frequency, percentage calculations and content analysis method were used. Result of qualitative analysis of obtained data, some perceptions have appeared to stand out that "Accounting as a difficult, boring and complex course", "accounting as a necessary, useful, important lesson" and "accounting as an exciting lesson" among the perceptions of the accounting course / concept of accounting education students. The most commonly used metaphor for each category of students participating in the survey are "black, lion (tiger), vegetable type, winter, hide-and-seek, cactus and calculator".

Keywords: Corporate Wisdom, Knowledge Management, Accounting Information System, Management Accounting.

Jel Classification: M00, M40, M41.

\footnotetext{
* Yrd.Doç.Dr. Sema Akpınar, Sakarya Üniversitesi İşletme Fakültesi, semaulku@sakarya.edu.tr

** Yrd.Doç.Dr. Şule Yıldız, Sakarya Üniversitesi İşletme Fakültesi, kasapoglu@sakarya.edu.tr
} 


\section{GİRiş}

Muhasebe bilgi kullanıcılarının ve muhasebeden elde edilen faydaların çeşitliliği, muhasebenin farklı disiplinlerle (hukuk, ekonomi, eğitim, pazarlama vb.) etkileşim içinde olması ve muhasebe mesleğini seçim amacının kişiden kişiye farklılık göstermesi gibi nedenlerden dolayı "muhasebe" olgusu, farklı kişilerde farklı çağrışımlar oluşturabilmektedir. Muhasebenin zaman içinde işletme yönetimi açısından değişen ve gelişen rolü muhasebeye olan bakış açısını da etkilemiştir. Buna bağlı olarak muhasebe öğreticileri, muhasebe meslek mensubu adayları, muhasebe eğitimi alan öğrenciler, işletme yöneticileri vb. muhasebeyle ilişkili grup algılarında da değişiklikler meydana gelmiştir.

Muhasebe denildiğinde insanların aklına genelde soğuk, kuralcı, sıkıcı ve sıradanlaşmış bir kavram gelmektedir. Bunun nedeni muhasebenin, bu meslekle ilgilenen kişilere sadece defter kaydı tutma, tekrarlayıcı ve monoton hesap işlemleriyle uğraşma gibi bazı görev ve sorumlulukları yüklediği düşüncesi ve algısıdır. Artan önemine rağmen muhasebe kavramı bu türden olumsuz algılamaları hak etmemektedir. Muhasebe eğitimini olumsuz yargılamalardan kurtarmak adına, bu düşüncelerin altında yatan nedenleri keşfetmek ve gerekli çözümleri üretmek gerekmektedir (Erol ve Demirel Utku, 2015:1308).

Muhasebe eğitimi alan öğrencilerin potansiyel meslek mensubu olma yolunda gerekli bilgi ve beceriyi edinme sürecinin temelleri genel muhasebe dersi ile atılmaktadır. Bu aşamada dersin anlaşılmasını ve etkili öğrenmeyi zorlaştıran etkenlerden biri de öğrencilerdeki isteksizlik ve muhasebeye ilişkin olumsuz algılardır. Bu noktada, metaforlar öğrencilerin muhasebeye ilişkin algılarını incelemede kullanılabilecek araçlardan biridir.

Dilimizdeki karşılığı "mecaz, eğretileme, benzetme" olan metaforlar, genelde benzer bir alandan yeni ve çoğunlukla bilinmeyen bir alana bilgi transferini kapsamaktadır. Dolayısıyla metaforlar olayların oluşumuna ve ilerleyişine ilişkin düşüncelerimizi yapılandıran, yönlendiren ve kontrol eden en güçlü zihinsel araçlardır (Miller,1987). Cerit (2008:694)'e göre metaforlar; insanların farklı benzetmeler kullanarak, hayatı, çevreyi, olayları ve nesneleri nasıl gördüklerini açıklamada kullandıkları bir araçtır. Yob (2003) ise, metaforu, bir bireyin yüksek düzeyde soyut, karmaşık veya kuramsal bir olguyu anlamada ve açıklamada kullanabileceği güçlü bir araç olarak tanımlamıştır. Örneğin, "küresel ısınma deprem gibidir" diyen bir kişi küresel ısınmanın neden olduğu tüm değişiklikleri ayrıntılı bir şekilde açıklamaktansa dünya üzerindeki yıkıcı etkilerinden yola çıkarak kendine daha tanıdık gelen deprem kavramını kullanmaktadır. Bir diğer deyişle, deprem metaforundan hareketle bu karmaşık kavramı tanımlamakta ve küresel 1sınma kavramına ilişkin algısını ortaya koymaktadır (Ateş ve Karatepe, 2013:1330-1331).

Metafor konusundaki araştırmalar incelendiğinde, genelde çalışmaların üç amaç etrafında toplandığı görülmektedir. Bunlar; metaforların yapısı ve oluşumuna ilişkin çalışmalar; metaforların herhangi bir konunun öğretiminde kullanılmasına yönelik çalışmalar ve metaforların çeşitli zihinsel algıları ortaya çıkarmak için kullanılmasına yönelik çalışmalardır (Yalçın vd., 2016:21).

Metaforların bir öğretim aracı olarak kullanılmasının en önemli nedeni uzun süre akılda tutmayı sağlayıcı bir ortam oluşturabilmesidir. Metaforlar, öğrenme için faydalı olup motivasyonu artırır, sezgileri geliştirebilir, duyusal gelişimi iyileştirebilir, isteksizliği ve ders 
korkusunu ortadan kaldırıp yaratıcı ve keşfedici öğrenme sağlayabilir. Metaforlar öğretmenleri öğrencilerin geçmiş tecrübe ve bilgilerini dikkate almaya zorlayarak, daha önceki konularla ilgili öğrenmelerdeki muhtemel yanlış anlamaların da ortaya çıkarılmasını sağlar (Arslan ve Bayrakçı, 2006:103-104). Bunların yanında metaforlar, kişilerin inançları, tutumları, beklentileri ve algılarının tespitine yönelik bilimsel araştırma sürecinde de önemli bir veri toplama tekniği olarak kullanılmaktadır (Aslan, 2015:366; Taşdemir ve Taşdemir, 2016: 423; Ayyıldız, 2016:14). Farklı grupların, farklı zihinsel imgelere açık, soyut kavramlar üzerindeki algılarını metaforlar yoluyla belirlemeye çalışan araştırmalar, söz konusu kavramlarla ilgili faaliyetlerde bilgi alışverişi ve etkin iletişimi sağlama açısından faydalı olabilmektedir (Saçllık vd., 2016: 85).

Başta eğitim bilimi olmak üzere, sosyal bilimlerin farklı disiplinlerinde metaforlar üzerine yapılan çalışmalar son yıllarda giderek artmakla birlikte (Walters York, 1996; Uysal, 2001; Jones ve Fields, 2001; Semerci, 2007; Cerit, 2008; Saban, 2008-2009; Uçma, 2010; Kesen, 2010; Hacıfazlıŏglu vd., 2011; Demirci Güler, 2012; Nalçacı ve Bektaş, 2012; Onay ve Ergüden, 2012; Soysal ve Afacan, 2012; Mertol vd., 2013; Tortop, 2013; Karaçam ve Aydın, 2014; Demirtaş ve Çoban, 2014a-2014b; Başarır ve Sarı, 2015; Ayyıldız, 2016; Cansever ve Aslan, 2016; Doğan, 2017 vb.) muhasebe kavramına ilişkin araştırmalar oldukça azdır. $\mathrm{Bu}$ yönüyle araştırmanın literatürdeki bu boşluğu gidermede faydalı olacağı düşünülmektedir.

Araştırma, potansiyel birer meslek mensubu veya muhasebe öğretim elemanı adayı olan öğrencilerin muhasebeye yönelik algı, tutum ve düşüncelerinin tespiti ve varsa olumsuz algıların giderilmesine yönelik tedbirlerin alınması açısından önemli olduğu gibi aynı zamanda muhasebe öğreticilerinin öğrencilerin muhasebe eğitimine yönelik tavır ve önyargılarının altında yatan nedenleri ortaya çıkarmada kullanabilecekleri bir yol olarak da kullanılabilir. $\mathrm{Bu}$ noktada öğrencilerin derse ilişkin bakış açılarının anlaşılması, öğretim elemanlarına dersin işlenişi ve aktarımı konusunda yardımcı olabilecektir. Muhasebe öğretim elemanlarının dersi anlatırken sergiledikleri tutum öğrencinin derse/mesleğe olan bakış açısını etkileyecektir. Muhasebe dersine yönelik pozitif tutum ve değer yargılarına sahip olan öğrenciler ise dersi sever, ilgi duyar ve başarılı olabilirler. Nitekim Aygün ve Gerekan, (2012:50) muhasebe dersini ilk kez alan öğrencilerin bu derse ilişkin algılamalarının dersteki başarı durumunu etkilediğini belirtmişlerdir. Yine Ertaş ve Erdem (2008:81), çalışmalarında öğrencilerin muhasebe derslerine ilişkin olumsuz algıları (dersi sevmemeleri, çok karmaşık ve anlaşılması güç bulmaları ve sahip oldukları önyargılar) ile ders başarıları arasında negatif yönlü anlamlı bir ilişki tespit etmişlerdir.

Daha önce ülkemizde öğrencilerin muhasebe derslerine olan tutum ve algılarını ortaya çıkarmayı amaçlayan çalışmalar yapılmakla birlikte, bu çalışmada muhasebe kavramı, farklı bir düşünce olan "metafor" yöntemi ile değerlendirilmiştir. Bu doğrultuda, öncelikle çalışma ile ilgili literatür incelenmiş, sonra araştırma neticesinde elde edilen bulgular değerlendirilmiş, daha sonra ise sonuç ve önerilere yer verilmiştir.

\section{LITERATÜR TARAMASI}

Yapılan literatür incelemesinde, muhasebe dersine yönelik öğrenci algı ve tutumlarının incelendiği çalışmalar aşağıdaki gibidir: 
Geiger ve Ogilby (2000), Muhasebeye giriş dersini alan 331 öğrencinin dönem başı ve dönem sonu derse yönelik algılarında herhangi bir farklılık olup olmadığını ölçmüş, dönem başında olumlu olan tutumun dönem sonunda azaldığını tespit etmişlerdir.

Jones ve Fields (2001), çalışmalarında muhasebeye giriş dersini alan öğrencilerin, derse ilişkin cesaretsizlik ve başarısızlık gibi duygulara sahip olduğunu ve genel olarak muhasebeyi olumsuz algıladıklarını belirlemiş̧lerdir.

Ağca ve Zeytinoğlu (2008), Kütahya Dumlupınar Üniversitesi ve Eskişehir Anadolu Üniversitesi İ.İ.B.F' lerinde öğrenim gören 819 öğrenci üzerindeki yaptıkları çalışmada, son sınıf öğrencilerinin birinci sınıf öğrencilere göre muhasebe mesleğine ilişkin daha olumsuz tutumlara sahip olduklarını ifade etmişlerdir.

Köse ve Gürbüz (2009), muhasebeye giriş dersini almış olan 566 öğrenciye yönelik yaptıkları çalışmada, temel kavramların anlaşılması, konuya olan ilgi, motivasyon, organizasyon, geribildirim ve değerlendirme konularında öğrencilerin olumlu görüşe sahip olduğunu; fakat görüşlerin değişmesi, aktif öğrenme ve öğretmen-öğrenci ilişkisi konularında ise olumsuz görüşe sahip olduğunu tespit etmişlerdir.

Özcan vd., (2009), Akdeniz Üniversitesi'ne bağlı bir Meslek Yüksekokulu’nda мuhasebe Bölümü öğrencilerinin mesleğe yönelik tutumunu tespit etmeye yönelik yaptıkları çalışmada; öğrencilerin muhasebe programından memnun kaldıklarını, eğitimlerinin iş bulmada önemli katkılar sağlayacağını ve toplumun mesleğe bakışının pozitif yönde olduğunu düşündüklerini tespit etmişlerdir. Bu bağlamda araştırmaya dahil olan öğrenciler muhasebe mesleğine olumlu yönde yaklaşmışlardır.

Gökgöz (2012) çalışmasında, Yalova Üniversitesinde genel muhasebe dersini alan 195 öğrenciye anket uygulayarak muhasebeci kavramına ilişkin metaforik algılarını tespit etmeye çalışmıştır. Yapılan içerik analizi sonucunda, en sık kullanılan metaforlar hesap makinesi, bahçıvan, karınca, matematikçi ve tilki olarak tespit edilmiştir. Kullanılan metaforlar incelendiğinde en çok vurgu yapılan muhasebeci algısı olarak "muhasebeciler etik değerlere bağlı değildir" olmuştur.

Aygün ve Gerekan, (2012) tarafından muhasebeye giriş dersini iki farklı üniversitede alan 532 öğrencinin derse yönelik algılarının, dönem sonunda dönem başına kıyasla farklılaşıp farklılaşmadığının ölçüldüğü çalışma sonucunda, dönem başında öğrencilerin derse karşı ilgisiz olduğu, bu dersi aldıktan sonra ise öğrenci tutumlarında olumlu bir değişim meydana geldiği tespit edilmiştir.

Gökgöz ve Dizkırıcı (2013) tarafından Yalova Üniversitesinde öğrenim gören 195 öğrenci üzerinde yapılan çalışmada, öğrencilerin muhasebeye ilişkin en çok kullandıkları metaforlar matematik, hesap makinesi, puzzle, terazi ve bilmece olarak tespit edilmiştir. Pearson ki kare testi kullanarak yapılan analizde cinsiyet ve eğitim şekli (Yüksekokul/İşletme Fakültesi öğrencileri ile kullanılan metaforlar arasında anlamlı bir ilişkiye rastlanmamıştır. Kullanılan metaforlardan yola çıkılarak yapılan içerik analizi sonucu "muhasebede sonuca ulaşmak için aşamalardan geçmek gerekir" "muhasebe matematiksel işlemlerden oluşmaktadır" ve "muhasebe aynı işlemlerin tekrarıdır" ve "muhasebe para demektir" kategorileri ön plana çıkmıştır. 
Ertuğrul ve Özdemir (2014) muhasebe dersi alan ön lisans ve lisans öğrencilerinin derse yönelik tutumlarının tespitini amaçlayan çalışmalarında, 821 öğrenciye anket uygulamışlardır. Araştırma sonucunda, öğrencilerin muhasebe derslerine karşı tutumları "Gereksiz, Sıkıcı ve Angarya", "İstekli ve Arzulu", "Gereklilik", “İsteksizlik" ve "Amaçsızlık" olarak beş grupta toplanmıştır.

Yıldırım (2015), çalışmasında, muhasebeye giriş dersini alan 62 hukuk fakültesi öğrencisinin genel muhasebe dersine ilişkin görüşlerini incelemiş, elde edilen sonuçlara göre öğrencilerin cinsiyete göre başarı, kariyer, ödül, zaman, merak veya zevkli, zor, sıkıcı, motivasyon, bilgi, eğitici puan ortalamaları arasında bir farklılık bulunmamıştır. Yine, öğrencilerin bekledikleri ve aldıkları ders notları bakımından kadın öğrenciler lehine anlamlı bir fark bulunmuştur.

Özbek (2015), çalışmasında, farklı eğitim programlarındaki öğrencilerin muhasebe algısını ölçmek için 102 öğrenci ile anket çalışması yapmış, sonuçta genel olarak öğrencilerin muhasebe dersinin gerekliliği konusunda farkında ve istekli olduklarını ortaya koymuştur.

Erol ve Demirel Utku (2015), ilk kez muhasebe dersi alan öğrencilerin, dönem başı ve sonundaki algılamalarındaki farklılaşmaları belirlemek amacıyla 164 öğrenci üzerinde yaptıkları çalışmada, Genel Muhasebe dersine dönem başındaki bakış açılarının ve algılamalarının, genel olarak, dönem sonuna göre daha negatif olduğu sonucuna ulaşmışlardır.

Güler vd., (2016), Dumlupınar Üniversitesi İ.İ.B.F. de muhasebe eğitimi alan 200 öğrencinin "muhasebeci" metaforları algılarını belirlemeye çalıştıkları araştırmada, genel olarak öğrencilerin en çok kullandıkları metaforların parasal kavramlar olduklarını ortaya koymuşlardır.

\section{METODOLOJÍ}

\subsection{Araştırmanın Amacı ve Önemi}

Çalışmanın amacı, muhasebe eğitimi alan öğrencilerin muhasebe kavramına ilişkin algılarını metaforlar yardımıyla belirlemektir. Özellikle muhasebe ile ilk kez tanışılan ders olan genel muhasebe dersini alan öğrencilerin muhasebeye bakış açılarının ve algılarının metaforlar yoluyla tespiti, öğrencilerin muhasebeye yönelik olumsuz algılarının sebeplerinin anlaşılmasında faydalı olabileceği gibi öğretim elemanları açısından da, muhasebenin faydaları, gerekliliği ve önemi konusunda ilk derslerde daha fazla bilgi verilmesi konusunda farkındalık oluşturabilecektir.

\subsection{Araştırmanın Kapsamı ve Yöntemi}

Araştırma, 2015-2016 öğretim yılının bahar döneminde Sakarya Üniversitesi İşletme ve Siyasal Bilgiler Fakülteleri bünyelerinde yer alan İşletme, Sağlık Yönetimi, Finansal Ekonometri ve Yönetim Bilişim Sistemleri bölümlerinde öğrenim gören toplam 271 öğrencinin katılımıyla gerçekleştirilmiştir. Bu bölümlerde genel muhasebe dersine kayıtlı öğrenci sayısı 310 olup ana kütlenin evreni temsil etme oranı yaklaşık \% 87 dir. 
Araştırmada son ders saati içinde yüzyüze anket yöntemi uygulanmış ve katılımcıların ankette yer alan "“"Eğer muhasebe bir renk (hayvan, besin türü, mevsim, oyun, çiçek ve eşya) olsaydı, “......"olurdu. Çünkü”....." cümlelerini tamamlamaları istenmiştir. Aynı zamanda katılımcıların yaş, cinsiyet, öğretim türü, bölüm, muhasebe mesleğine ilgi düzeyi gibi bazı demografik özellikleri ve muhasebe mesleğine bakış açılarına yönelik sorular da ankette yer almaktadır.

Verilerin analizinde içerik analizi yöntemi kullanılmış ve öğrencilerin verdikleri cevaplar, kullanılan metafor, metaforun kaynağ 1 , metaforun kaynağı ve gerekçesi arasındaki ilişki bakımından ayrıntılı olarak incelenmiştir. Bu doğrultuda, öncelikle her bir metafor (renk, hayvan vb.) için kullanılan metafor kaynağının öğrenciler tarafından kullanılma sıklığı tespit edilmiştir. Bu noktada hangi gerekçe ile kullanıldığı ifade edilmeyen ya da kullanılan metaforla muhasebe kavramı arasında anlamlı bir ilişki saptanamayan bazı metaforlar "İlişkisiz" kategorisi altında verilerek analiz dışında tutulmuştur. Örneğin "muhasebe bir mevsim olsaydı yaz olurdu. Çünkü yazı seviyorum " ifadesinde metafor olarak kullanılan yaz mevsimi ile muhasebe arasındaki ilişkiye dair mantıklı bir açıklama getirilemediğinden bu ve benzeri cevaplar analize katılmamıştır. Daha sonra belli ortak özellikleri içeren metaforlar belli kavramsal kategoriler altında toplanmıştır. Örneğin "muhasebe puzzle gibidir, çünkü çözmesi zordur, karmaşıktır, yoğun düşünce gerektirir"; "muhasebe siyah renge benzer, çünkü iç karartıcıdır ve en küçük bir hata hemen ortaya çıkar" "Muhasebe ayvaya benzer, çünkü ayvanın sindirimi zordur, muhasebe sürecinin anlaşılması da zaman ister.", "Muhasebe ceviz gibidir, nasıl ki cevizin içi karışık ise muhasebede de konular çok karışık" gibi ifadelerde muhasebenin zor ve sıkıcı bir ders olarak algılandığı sonucuna ulaşılmıştır. Bu nedenle belirlenen kategorilerden biri "zor, sıkıcı ve karmaşık bir ders olarak muhasebe “ olmuştur.

Sonuç olarak öğrencilerin kullandıkları metaforlar, muhasebe kavramına ilişkin içerdikleri anlamlar bakımından "Heyecan verici bir ders olarak muhasebe", " Zor, sıkıcı, karmaşık bir ders olarak muhasebe" "Kurall1, düzenli ve sistematik bir ders olarak muhasebe", "Diğer bilim dallarıyla ilişkili bir ders olarak muhasebe", " Yol gösterici bir ders olarak muhasebe", "Dikkat ve çok çalışma gerektiren bir ders olarak muhasebe", "Zeka gerektiren bir ders olarak muhasebe", "Gerekli, faydalı ve önemli bir ders olarak muhasebe", "Parayla ilişkili bir ders olarak muhasebe" şeklinde 9 kategori ile eşleştirilmiştir. Saban (2008, 2009), Güven ve Güven (2009), Güveli vd., (2011) de çalışmalarında farklı kavramlara ilişkin benzer bir veri analiz yöntemi kullanmışlardır.

Araştırmanın geçerlik ve güvenirliğinin belirlenmesinde bu alandaki uzman görüşlerinden yararlanılmıştır. Uzmanın, çalışmada belirlenen kavramsal kategorilere ilişkin düşünceleri alınmıştır. Araştırmacılar ve uzmanlar arasındaki görüş birlik ve farklılıklarının sayısı tespit edilerek Miles ve Huberman'ın (1994) Güvenirlik=görüş birliği/(görüş birliği+görüş ayrılığı) formülü kullanılarak çalışmanın güvenirliği \%92 olarak hesaplanmıştır.

\section{UYGULAMA}

Araştırma bulguları iki aşamalı olarak analiz edilmiştir. İlk olarak öğrencilerin demografik bilgileri, muhasebe mesleği ve genel muhasebe dersine ilişsin düşüncelerine ait frekans ve yüzdeler verilmiştir. Daha sonra ise öğrencilerin muhasebe kavramına ilişkin yedi metafor başlığı (renk, hayvan, besin türü, mevsim, oyun, çiçek, eşya) için geliştirdikleri 
metaforlar, bunlar içinde dikkat çekici olan birkaç örnek ile birlikte tablolar halinde sunulmuştur. Son olarak bu yedi metafor başlığı altında verilen cevaplar incelenmiş ve muhasebe kavramının değişik yönlerine vurgu yapan metaforların ortak özellikleri dikkate alınarak öğrencilerin muhasebe kavramına ilişkin algıları dokuz kategori altında toplanmıştır.

Tablo 1. Katılımcıların Demografik Özellikleri

\begin{tabular}{|c|c|c|c|}
\hline Demografik Özellikler & Cevap & Frekans & $\%$ \\
\hline \multirow[t]{3}{*}{ Yaş } & 20 yaş ve altı & 120 & 44,3 \\
\hline & 21 yaş ve üstü & 151 & 55,7 \\
\hline & Toplam & 271 & 100,0 \\
\hline \multirow[t]{3}{*}{ Cinsiyet } & Kadın & 139 & 51,3 \\
\hline & Erkek & 132 & 48,7 \\
\hline & Toplam & 271 & 100,0 \\
\hline \multirow[t]{3}{*}{ Öğretim Türü } & I. Öğretim & 220 & 81,2 \\
\hline & II. Öğretim & 51 & 18,8 \\
\hline & Toplam & 271 & 100,0 \\
\hline \multirow[t]{5}{*}{ Bölüm } & Finansal Ekonometri & 33 & 12,2 \\
\hline & İşletme & 141 & 52 \\
\hline & Sağlık Yönetimi & 65 & 24 \\
\hline & Yönetim Bilişim Sistemleri & 32 & 11,8 \\
\hline & Toplam & 271 & 100,0 \\
\hline \multirow[t]{3}{*}{ Mezun Olunan Lise } & Ticaret Lisesi & 13 & 4,8 \\
\hline & Diğer & 258 & 95,2 \\
\hline & Toplam & 271 & 100,0 \\
\hline
\end{tabular}

Tablo 1'e göre, ankete katılan öğrencilerin \% 44.3' ü 20 yaş altı, \% 55.7'si 21 yaş ve üstü yaş aralığındadır. Yine katılımcıların \%51.3'ü kadın, \%48.7'si erkek, \%81.2' si I.öğretim, \%18.8' i II.öğretim, \%12.2' si Finansal Ekonometri, \%52' si İşletme, \%24 ü Sağlık Yönetimi, \%11.8' i Yönetim Bilişim Sistemleri öğrencisidir. Öğrencilerin büyük çoğunluğu (\%95.2) Ticaret lisesi mezunu değildir.

Tablo 2. Katılımcıların Muhasebe Mesleği ve Genel Muhasebe Dersine İlişsin Genel Özellikleri

\begin{tabular}{|c|c|c|c|}
\hline \multicolumn{2}{|c|}{ Muhasebe Mesleği İle İlgili Genel Sorular } & Frekans & $\%$ \\
\hline \multirow[t]{3}{*}{ Muhasebe Mesleğine İlgi Düzeyi } & Düşük & 96 & 35,4 \\
\hline & Orta & 155 & 57,2 \\
\hline & Yüksek & 20 & 7,4 \\
\hline \multirow[t]{2}{*}{ Ailede Muhasebe Meslek Mensubu Varlığ 1} & Evet & 74 & 27,3 \\
\hline & Hayır & 197 & 72,7 \\
\hline \multirow[t]{2}{*}{ Mezuniyet Sonrası Muhasebe Mesleğini Seçme } & Evet & 64 & 23,6 \\
\hline & Hayır & 207 & 76,4 \\
\hline \multicolumn{2}{|c|}{ Genel Muhasebe Dersi İle İlgili Sorular } & Frekans & $\%$ \\
\hline
\end{tabular}




\begin{tabular}{|c|c|c|c|}
\hline \multirow[t]{2}{*}{ Sınıf geçmek için derse çalışıyorum. } & Evet & 192 & 70,8 \\
\hline & Hayır & 79 & 29,2 \\
\hline \multirow[t]{2}{*}{ Dersle ilgili bakış açımı geliştirmek için çalışıyorum } & Evet & 152 & 56,1 \\
\hline & Hayır & 119 & 43,9 \\
\hline \multirow[t]{2}{*}{ İleriki iş hayatıma yardımcı olması için çalışıyorum } & Evet & 202 & 74,5 \\
\hline & Hayır & 69 & 25,5 \\
\hline \multirow{2}{*}{$\begin{array}{l}\text { Akademik kariyer planımda yardımcı olması için } \\
\text { çalışıyorum }\end{array}$} & Evet & 131 & 48,3 \\
\hline & Hayır & 140 & 51,7 \\
\hline \multirow[t]{2}{*}{ İşletmedeki temel işleyişi anlamak için çalışıyorum } & Evet & 182 & 67,2 \\
\hline & Hayır & 89 & 32,8 \\
\hline \multirow[t]{2}{*}{ Dersin İlk Kez Alınıp Alınmadığı } & İlk kez & 192 & 70,8 \\
\hline & Alttan & 79 & 29,2 \\
\hline \multirow[t]{4}{*}{ Derse Çalışmak İçin Harcanan Haftalık Süre } & $\begin{array}{l}\text { Sadece sinav } \\
\text { zamanı }\end{array}$ & 88 & 32,5 \\
\hline & 1 saatten az & 63 & 23,2 \\
\hline & 1-3 saat aras1 & 87 & 32,1 \\
\hline & 3 saatten fazla & 33 & 12,2 \\
\hline
\end{tabular}

Tablo 2 incelendiğinde, öğrencilerin yalnızca \%23.6' sının mezuniyet sonrası muhasebe mesleğini seçmeyi düşündüğü ve sadece \% 7.4 ' ünün muhasebe mesleğine yüksek derecede ilgi duyduğu görülmektedir. Öğrencilerin büyük çoğunluğunun (\%72.7) ailesinde muhasebe meslek mensubu yoktur. Öğrencilerin genel muhasebe dersine ilişkin sorulara verdikleri yanıtlar incelendiğinde, \%70.8' sinin dersi ilk kez aldığı ve yalnızca sınav zamanı derse çalışmak için zaman harcayan öğrenci oranının \%32.5 olduğu görülmektedir. Muhasebe dersine çalışma sebepleri araştırıldığı ve birden fazla seçeneğin işaretlendiği sorulara bakıldığında, \%70.8 sınıf geçmek için, \%56.1 dersle ilgili bakış açısını geliştirmek için, \%74.5 ileriki iş hayatına yardımcı olması için, \%48.3 akademik kariyer planında yardımcı olması için, \%67.2 de işletmedeki temel işleyişi anlamak için çalıştığını ifade etmiştir.

Aşağıdaki kısımda muhasebe eğitimi alan öğrenciler tarafından her bir imge için (renk, hayvan, besin türü, mevsim, oyun, çiçek, eşya) üretilen metaforların frekanslarına ilişkin bilgiler tablolar halinde verilmiştir. Ayrıca tablolarda bazı öğrencilerin metaforlara ilişkin dikkat çeken gerekçelerine de yer verilmiştir.

Tablo 3. Katılımcıların Bir Renk Olarak Muhasebe Algıları

\begin{tabular}{|c|c|c|c|c|}
\hline Renkler & \multicolumn{3}{|c|}{$\mathbf{f}$} & Çünkü \\
\hline & & Olumlu & 8 & $\begin{array}{l}\text { "Siyah bütün renklerle uyumludur, muhasebe de siyah gibi her türlü } \\
\text { işletmede kullanılır.", "Tipks siyah gibi muhasebede de her şey nettir, } \\
\text { belirsizlige yer yoktur.", }\end{array}$ \\
\hline Siyah & 75 & Olumsuz & 67 & $\begin{array}{l}\text { "Muhasebe de siyah gibi içimi karartan zor ve sıkıcı bir süreçtir.", } \\
\text { "Uzay boşluğu gibidir, İşleyişi çözemezsen her sene boşlukta savrulur } \\
\text { durursun." "Kara delik gibi içine çekiyor." "Nasll ki siyah üzerinde } \\
\text { en küçük bir toz bile belli olursa muhasebe de en küçük hatayı bile } \\
\text { kabul etmez." "Muhasebe bana kara kaplı defterleri hatırlatıyor.", }\end{array}$ \\
\hline Gri & 45 & Olumlu & 7 & $\begin{array}{l}\text { "Siyah ve beyazın birbirini tamamladığl gibi muhasebedeki işler de } \\
\text { birbirini tamamlar, kopukluk yoktur." "Önce biraz zor karanlık gibi, }\end{array}$ \\
\hline
\end{tabular}




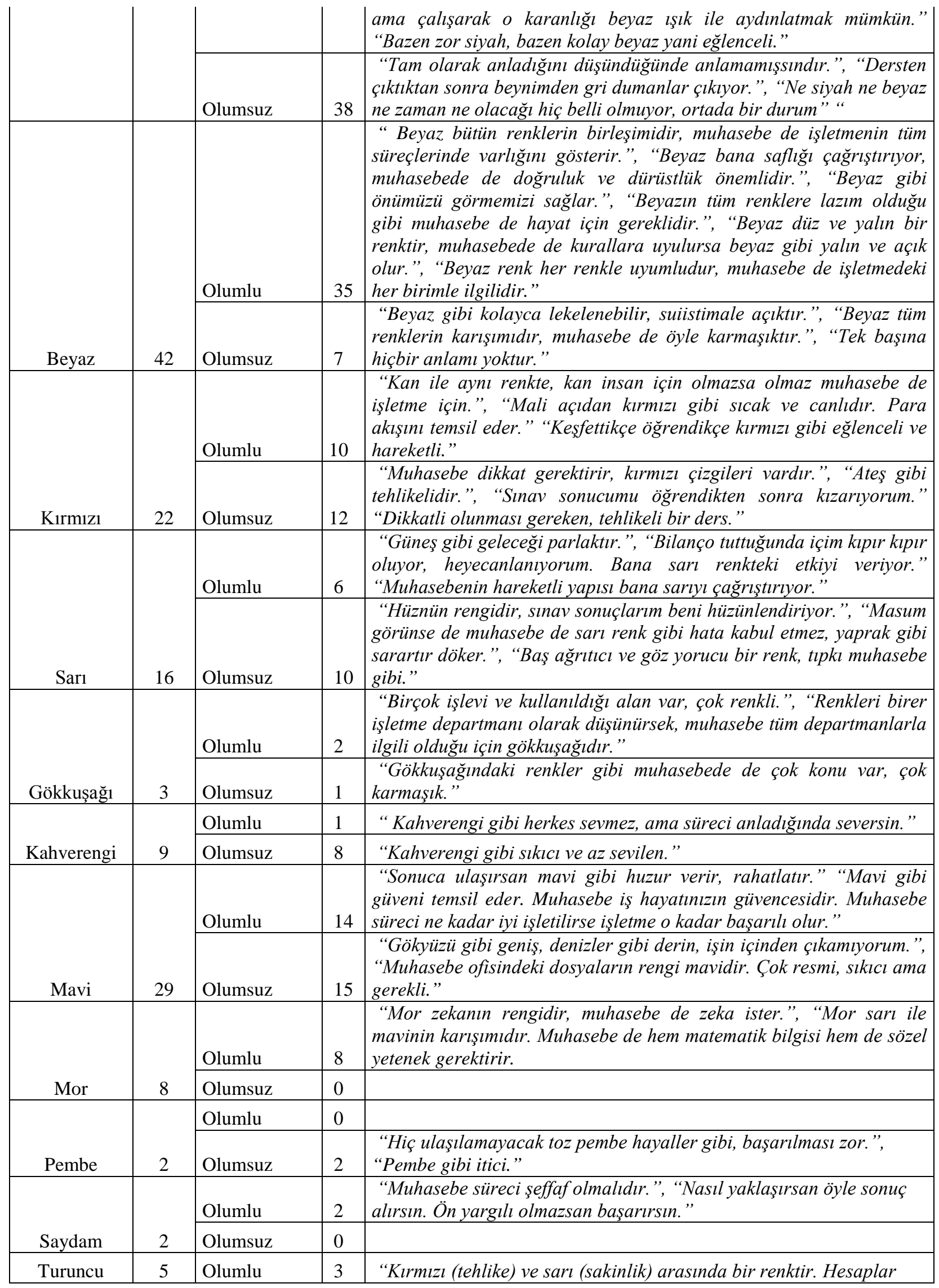




\begin{tabular}{|c|c|c|c|c|}
\hline & & & & $\begin{array}{l}\text { yanlı̧ssa kırmızı görünür, doğruysa sarı. Dikkatli olursan tehlikeden } \\
\text { uzak durursun." } \\
\text { "Turuncu eğlenceyi ifade eder, muhasebe de eğlencelidir." }\end{array}$ \\
\hline & & Olumsuz & 2 & “Uyumsuz bir renk, muhasebe dersi de benim için uyumsuz.” \\
\hline \multirow[b]{2}{*}{ Yeşil } & \multirow[b]{2}{*}{10} & Olumlu & 9 & $\begin{array}{l}\text { "Paranın rengi yeşildir, muhasebe mesleğinde de çok para kazanmak } \\
\text { mümkündür." "Yeşil huzurun rengidir, sonuçlar tuttuğunda huzura } \\
\text { kavuşursun." "Doğada her zaman yeşili görmek mümkündür, } \\
\text { işletmede her birim muhasebeyle ilişkilidir." }\end{array}$ \\
\hline & & Olumsuz & 1 & "Ağaç gibi dallara ayrılır, çok konu var çok karmaşıktır." \\
\hline İlişkisiz & 3 & \multicolumn{3}{|c|}{ 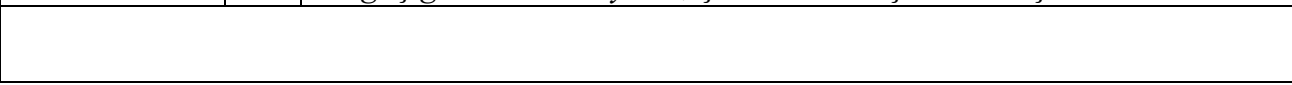 } \\
\hline Toplam & \multicolumn{4}{|r|}{271} \\
\hline
\end{tabular}

Tablo 3’te öğrencilerin “renk olarak muhasebe” algılarındaki farklılaşma olumlu ve olumsuz ayrımıyla birlikte frekans ve bazı gerekçelerle birlikte yer almaktadır. Siyah, gri ve beyaz renkler öğrenciler tarafindan en çok kullanılan metaforlardır. Söz konusu renkleri olumlu anlamda muhasebe ile ilişkilendiren öğrencilerin cevapları incelendiğinde, siyah rengin muhasebenin her işletmede kullanımının gerekliliği ve muhasebe işlemlerindeki netliği ifade etmede kullanıldığı; gri renk ile muhasebede işlemler arası bütünlük, çalışıldığında başarılacak ve eğlenceli bir ders olma; beyaz renk ile de muhasebenin işletmede tüm süreçlerdeki varlığı ve uyumuna, doğruluk, dürüstlük, yalın ve açık olmanın önemine, yol gösterici özelliğine vurgu yapıldığı görülmüsstür. Cevaplar, olumsuz vurgu yapan öğrenciler açısından incelendiğinde ise, siyah rengin muhasebenin zor, sıkıcı ve hata kabul etmeyen bir ders oluşuna; grinin muhasebenin anlaşılması zor, belirsiz ve stresli bir ders olmasına ve beyaz rengin ise muhasebe işlemlerinin suistimale açık, karmaşı olma ve tek başına fayda sağlamayışı özelliğine yönelik kullanıldığı tespit edilmiştir.

Tablo 4. Katılımcıların Bir Hayvan Olarak Muhasebe Algıları

\begin{tabular}{|c|c|c|c|c|}
\hline Hayvan & \multicolumn{3}{|c|}{ f } & Çünkü \\
\hline \multirow[b]{2}{*}{ Aslan/Kaplan } & \multirow[b]{2}{*}{27} & Olumlu & 17 & $\begin{array}{l}\text { "Ormanların krall gibi derslerin krall.", "Aslan gibi güçlï.", } \\
\text { "Aslanın hayvanların lideri olması gibi, muhasebe de yönetime } \\
\text { yol gösterir." }\end{array}$ \\
\hline & & Olumsuz & 10 & $\begin{array}{l}\text { "Korkudan karşısındaki insanı titretiyor.", "En ufak bir hatayl } \\
\text { kabul etmez, çok yırtıcl.", "Hem korkunç hem de çok güzel.", } \\
\text { "Hirçın, can yakan." }\end{array}$ \\
\hline \multirow[b]{2}{*}{ Ar1 } & \multirow[b]{2}{*}{12} & Olumlu & 8 & $\begin{array}{l}\text { "Arı gibi düzenli ve çok çalışırsan başarırsın.", "Arı dünyanın } \\
\text { besin zincirinin dengesini sağlar, muhasebe de işletmenin } \\
\text { dengesini sağlar.", "Arılardaki mükemmel sistem, muhasebede de } \\
\text { vardır." }\end{array}$ \\
\hline & & Olumsuz & 4 & $\begin{array}{l}\text { "Dersten sonra bir acı hissediyorsun, bir de bakmısssn iğnesiyle } \\
\text { seni sokmuss.", "Ball sayesinde faydalı olabilir ama iğnesini } \\
\text { unutmamak lazım." }\end{array}$ \\
\hline \multirow[b]{2}{*}{ Karınca } & \multirow[b]{2}{*}{23} & Olumlu & 6 & $\begin{array}{l}\text { " Hesaplı kitaplı hayvanlardir.", "İslerini bir gün sonraya } \\
\text { bırakmazlar, kurallddılar, muhasebe de aynı kartnca gibi kurall } \\
\text { ve zamanlıdır." }\end{array}$ \\
\hline & & Olumsuz & 17 & "Karınca gibi çok yoğun düzenli ve sıkı çallşmak gerekir." \\
\hline \multirow[b]{2}{*}{ Kedi } & \multirow[b]{2}{*}{26} & Olumlu & 2 & "Temiz ve özenlidir, aynı muhasebe gibi." \\
\hline & & Olumsuz & 24 & $\begin{array}{l}\text { "Nankördür, yanlışı telafisi zordur.", "Sakin ve uysal gibi } \\
\text { görünse de tek bir yanllş harekette tırmalayabilir." }\end{array}$ \\
\hline
\end{tabular}




\begin{tabular}{|c|c|c|c|c|}
\hline \multirow[b]{2}{*}{ Köpek } & \multirow[b]{2}{*}{22} & \multirow{2}{*}{$\begin{array}{l}\text { Olumlu } \\
\text { Olumsuz } \\
\end{array}$} & \multirow{2}{*}{13} & $\begin{array}{l}\text { "Güvenilir ve sadlkttr.", "Köpek gibi sahibine yardımcl, yol } \\
\text { gösterici.", "Yavru köpeğin eğitimi gibi muhasebede de } \\
\text { öğrendikçe birikimlerin artar." }\end{array}$ \\
\hline & & & & $\begin{array}{l}\text { "Köpek gibi parçalayıcl ve korkutucu, sevmeye çallsssan da } \\
\text { kendini sevdirmez.", "Istrı"”, "Devaml ilgi göstermek lazım.", } \\
\text { "Ne zaman ne yapacağını kestiremezsin, güvenilmez." }\end{array}$ \\
\hline \multirow[b]{2}{*}{ Tilki } & \multirow[b]{2}{*}{17} & Olumlu & 4 & "Zeki insanlar muhasebeyi anlayabilir.” \\
\hline & & Olumsuz & 13 & $\begin{array}{l}\text { "Kurnaz, hesapçı ve uyanı olmak gerekir.", "Kurnaz ve sinsidir. } \\
\text { Kolay görünüp insant şaşırtabiliyor." }\end{array}$ \\
\hline \multirow[b]{2}{*}{ Yilan } & \multirow[b]{2}{*}{15} & Olumlu & 1 & "Çoğu kişi sevmese de besin zincirinin önemli bir parçasıdır." \\
\hline & & Olumsuz & 14 & $\begin{array}{l}\text { "Korkutucu ve zehirli", "Muhasebe de yllan gibi soğuk ve } \\
\text { tiksindirici.", "İnsan çekiyor, slknyor, birakmıyor. Yapamadikça } \\
\text { sanki yutuyor." }\end{array}$ \\
\hline \multirow[b]{2}{*}{ Kaplumbağa } & \multirow[b]{2}{*}{9} & Olumlu & 2 & $\begin{array}{l}\text { "Yavaş ilerliyor ama istikrarll.", Konu ve kavramları bir günde } \\
\text { anlayamazsin. Ama planlı bir şekilde çallş̧rsan başarırsin. }\end{array}$ \\
\hline & & Olumsuz & 7 & "Sılkıcı, konular çok ağır ilerliyor." \\
\hline \multirow[b]{2}{*}{ Bukalemun } & \multirow[b]{2}{*}{14} & Olumlu & 2 & $\begin{array}{l}\text { "Her işletmede adaptasyon gücü kuvvetli.", "Her ortamda bir } \\
\text { şekilde işe yarlyor." }\end{array}$ \\
\hline & & Olumsuz & 12 & $\begin{array}{l}\text { "Her konunun zorluk düzeyi farkll", "Konular ilerledikçe işin } \\
\text { rengi değiş̧iyor.", "Duruma göre şekil allyor." }\end{array}$ \\
\hline \multirow[b]{2}{*}{ İnek } & \multirow[b]{2}{*}{8} & Olumlu & 7 & $\begin{array}{l}\text { "Hem sütünden hem etinden faydalanirı, muhasebe de öyledir. } \\
\text { Her alanda faydalıdır.", "Ne kadar beslersen, o kadar süt verir." }\end{array}$ \\
\hline & & Olumsuz & 1 & $\begin{array}{l}\text { "Daha çok ezbere dayalı olduğu için, inekleme tabirini } \\
\text { çağrıştırtyor." }\end{array}$ \\
\hline \multirow[b]{2}{*}{ Çita } & \multirow[b]{2}{*}{5} & Olumlu & 1 & "İşletmeyi ileri taşır." \\
\hline & & Olumsuz & 4 & "Çok hizlı ilerliyor, takip etmesi zor." \\
\hline \multirow[b]{2}{*}{ Kuș türleri } & \multirow[b]{2}{*}{13} & Olumlu & 2 & $\begin{array}{l}\text { "Temelini ögrenirsen, kuş gibi rahat olursun.", "Kartal gibi } \\
\text { işletmenin en güçlü departmanıdır." }\end{array}$ \\
\hline & & Olumsuz & 11 & $\begin{array}{l}\text { "Konuyu baştan kaçırırsan geri kalanı kuş gibi uçup gider." } \\
\text { "Dilinden anlamadı̆̆ın sürece muhabbet kuşu gibi kafa şişirirr." }\end{array}$ \\
\hline \multirow[b]{2}{*}{ Sinek } & \multirow[b]{2}{*}{6} & Olumlu & 0 & \\
\hline & & Olumsuz & 6 & $\begin{array}{l}\text { "Hiçbir yararl yoktur, rahatsız edicidir.", "Yorucu ve kan } \\
\text { emici." }\end{array}$ \\
\hline \multirow[b]{2}{*}{ Diğer } & \multirow[b]{2}{*}{64} & Olumlu & & $\begin{array}{l}\text { "Kaz gibidir. Su yüzeyinde çok sakin ve basit gözükse de suyun } \\
\text { altında çallşan ayaklar (hesaplar) vardır." "Sirtına yük binen } \\
\text { eşek gibi, işletmenin tüm yükünü çeker." "Fil gibi, işletmenin } \\
\text { temelini oluşturur.", "Ahtapot gibi bağlantıll olduğ çok konu } \\
\text { var." }\end{array}$ \\
\hline & & Olumsuz & & $\begin{array}{l}\text { "Balık hafizası gibi, çabuk unutulan bir ders.", "Kirpi gibi } \\
\text { yaklaşttkça insanin canını yaklyor." }\end{array}$ \\
\hline İlişkisiz & 10 & & & \\
\hline Toplam & \multicolumn{4}{|r|}{271} \\
\hline
\end{tabular}

Tablo 4'te görüldüğü gibi öğrencilerin bir hayvan olarak muhasebeye yönelik geliştirdikleri oldukça çeşitli metaforlar arasında ön plana çıkanlar aslan/kaplan, kedi ve karıncadır. Aslan/kaplan benzetmesi yapan öğrenciler tarafından kullanılan gerekçelerden olumlu yönde öne çıkanlar, muhasebenin derslerin kralı gibi her dersle ilişkili olduğu düşüncesi, güçlü ve yönetime yol gösterici olma özelliği, olumsuz benzetimler ise, muhasebenin hata kabul etmeyen ve can yakıcı bir ders olduğu düşüncesidir. Kedi benzetmesi yapan öğrencilerce ön plana çıkan gerekçeler olumlu manada, muhasebenin özen gösterilmesi 
gereken bir ders olması, olumsuz manada ise nankör, yanlışların telafisinin zor olması düşüncesiyle ifade edilmiştir. Muhasebeyi karıncaya benzeten öğrenciler ise genel olarak muhasebenin yoğun, düzenli ve sıkı çalışılması gereken bir ders olduğunu, aynı zamanda da muhasebede kurallara ve zamana dikkat edilmesi gerektiğini ifade etmişlerdir.

Tablo 5. Katılımcıların Bir Besin Türü Olarak Muhasebe Algıları

\begin{tabular}{|c|c|c|c|c|}
\hline Besin Türü & \multicolumn{3}{|c|}{ f } & Çünkü \\
\hline \multirow[b]{2}{*}{ Sebze türleri } & \multirow[b]{2}{*}{87} & Olumlu & 28 & $\begin{array}{l}\text { "Her mevsimde bulunur, muhasebe de hayat boyunca } \\
\text { yanımızdadır.", "Besleyicidir.", "Sağlıklıdır, gereklidir, } \\
\text { faydalıdır.", "Çoğu yemekte bulunur, muhasebe de her işletmede } \\
\text { bulunur." "Ispanak yemiş gibi ögrendikçe kendimi güçlü } \\
\text { hissediyorum." "Işletmelerin güçlü ve ayakta kalması için } \\
\text { önemlidir." }\end{array}$ \\
\hline & & Olumsuz & 59 & “Tatsız”, “Sevimsiz”, “Herkes sevmez.” \\
\hline \multirow[b]{2}{*}{ Ekmek } & \multirow[b]{2}{*}{12} & Olumlu & 12 & $\begin{array}{l}\text { "Hayatidir.”, “Ekmeksiz yemek karın doyurmaz, muhasebesiz } \\
\text { ticaret faydall olmaz.”, "Ekmek gibi muhasebe de İşletme için } \\
\text { temelidir." }\end{array}$ \\
\hline & & Olumsuz & 0 & \\
\hline \multirow[b]{2}{*}{$\mathrm{Su}$} & \multirow[b]{2}{*}{13} & Olumlu & 13 & $\begin{array}{l}\text { "Susuz hayat, muhasebesiz işletme düşünülemez", "Muhasebe } \\
\text { işletmenin yaşam kaynağıdır.", "Her zaman ihtiyacımız olacak.", } \\
\text { "Hayati, vazgeçilmez." }\end{array}$ \\
\hline & & Olumsuz & 0 & \\
\hline \multirow[b]{2}{*}{ Meyve türleri } & \multirow[b]{2}{*}{30} & Olumlu & 25 & $\begin{array}{l}\text { "Karpuz gibi dışı sert ama açınca tadı güzel.", "Portakal C } \\
\text { vitamini içerir ve günlük alınmazsa bir işe yaramaz. Muhasebede } \\
\text { de konuları günlük olarak tekrarlamak gerekir.", "Faydalıdır, } \\
\text { enerji verir." "Ekşi de olsa seversin." }\end{array}$ \\
\hline & & Olumsuz & 5 & $\begin{array}{l}\text { "Ayvanın sindirimi zordur, muhasebe sürecinin anlaşılması da } \\
\text { zaman ister.", "Ceviz gibi içi çok karışık.", Hindistan cevizi gibi } \\
\text { yemek için uzun aşamaların atlatılması lazım. Muhasebede de } \\
\text { sonuca kolay ulaşamıyoruz.", "Nar taneleri gibi muhasebede de } \\
\text { içini açtıkça konular çoğalıyor." }\end{array}$ \\
\hline \multirow[b]{2}{*}{ Et } & \multirow[b]{2}{*}{9} & Olumlu & 7 & $\begin{array}{l}\text { "Faydast büyük, besin değeri yüksek.” “Olmazsa olmaz, } \\
\text { muhasebe de,işletme için öyle." }\end{array}$ \\
\hline & & Olumsuz & 2 & $\begin{array}{l}\text { "Birçok yemeği yapılır ama maliyetlidir.", "Yeterince } \\
\text { uğraşmadan iyi sonuç elde edemezsin." }\end{array}$ \\
\hline \multirow[b]{2}{*}{ Karbonhidrat } & \multirow[b]{2}{*}{30} & Olumlu & 21 & $\begin{array}{l}\text { "Her şekilde kullanılabilir.", "Güç ve enerji verir, muhasebe de } \\
\text { öyle.", "Tadl güzel ve besleyici.", "Temel bir besin grubudur, } \\
\text { muhasebe de işletmede temeldir." }\end{array}$ \\
\hline & & Olumsuz & 9 & "Fazlast vücuda zarar veriyor, muhasebe de öyledir." \\
\hline \multirow[b]{2}{*}{ Protein } & \multirow[b]{2}{*}{20} & Olumlu & 20 & $\begin{array}{l}\text { "Yapıtaşıdır, muhasebe de işletme için öyledir.", "Faydalıdır, } \\
\text { vücut için olmazsa olmaz.", "Güç verir." }\end{array}$ \\
\hline & & Olumsuz & 0 & \\
\hline \multirow[b]{2}{*}{ Yağ } & \multirow[b]{2}{*}{3} & Olumlu & 1 & "Muhasebe de yağ gibi az da olsa gerekli." \\
\hline & & Olumsuz & 2 & "Çalışması zor, yă̆l eritmek gibi.", "Săğlıksız." \\
\hline \multirow[b]{2}{*}{ Diğer } & \multirow[b]{2}{*}{45} & Olumlu & 25 & $\begin{array}{l}\text { "Bal gibi yararll ve yoğun”, "Çerez gibi ĕ̆lenceli”, "Tuzsuz } \\
\text { yemek, muhasebesiz işletme olmaz." }\end{array}$ \\
\hline & & Olumsuz & 20 & $\begin{array}{l}\text { "Salata (çorba, aşure ve türlü) gibi çok karışık”, "Tuz gibi } \\
\text { fazlası zararlı.", "Acı biber gibi acıtır." }\end{array}$ \\
\hline İlişkisiz & 22 & & & \\
\hline Toplam & \multicolumn{4}{|r|}{271} \\
\hline
\end{tabular}


Bir besin türü olarak öğrencilerin muhasebe algılarını gösteren Tablo 5 incelendiğinde, muhasebenin en çok sebze, meyve ve karbonhidrata benzetildiği görülmektedir. Olumlu görüş bildiren öğrenciler, muhasebenin işletmelerin güçlü olması için gerekli ve faydalı olduğunu ifade etmek için sebze ve meyveyi kullanmışlardır, benzer şekilde öğrenciler karbonhidratı da temel besin grubu olması dolayısıyla muhasebeye benzetmişlerdir. Bazı öğrenciler ise muhasebenin, sebze gibi tatsız, sevimsiz olduğunu, karbonhidrat gibi fazla alındığında zarar verdiğini, bazı meyvelerin görünüşü gibi (nar, ceviz) karışık ve konuların çok olduğunu ifade etmişlerdir.

Tablo 6. Katılımcıların Bir Mevsim Olarak Muhasebe Algıları

\begin{tabular}{|c|c|c|c|c|}
\hline Mevsimler & \multicolumn{3}{|c|}{$\mathbf{f}$} & Çünkü \\
\hline \multirow[b]{2}{*}{ İlkbahar } & \multirow[b]{2}{*}{46} & Olumlu & 28 & $\begin{array}{l}\text { "Yaz gelirken baharın getirdiği düzenleyicilik, aynı muhasebenin yeni } \\
\text { dönemler için yaptığl hazırlık gibi." "Ilkbahar gibi yoğun ve } \\
\text { hareketli." "Anladıkça insanın içine bahar sevinci doğuyor, içimiz } \\
\text { kıpır kıpır oluyor." "Illkbahar yazın nasıl geleceği hakkında bize bilgi } \\
\text { verir, muhasebede işletmenin geleceği hakkında." "Sonuca ulaştıkça } \\
\text { huzur ve moral verir". "Kıştan sonra gelir, iyi bir muhasebe de } \\
\text { işletmeyi zarardan kurtarabilir." "Ne yaz gibi kavurur ne de klş gibi } \\
\text { dondurur, dengelidir, muhasebede de denge önemlidir." "Yeni } \\
\text { başlanglçlar doğurur, meyveler olmaya başlar, bilanço hazırlığl } \\
\text { yapılır". }\end{array}$ \\
\hline & & Olumsuz & 18 & $\begin{array}{l}\text { "Yağmurlu da geçebilir, güneşli de, ne olacağ belli olmaz." } \\
\text { "Muhasebede de tamamen yazı yaşayamazsın, hep inişs çıkışlar olur". } \\
\text { "Tam yaz geldi diye sevinirken, bir anda şimşekler çakıp çamura } \\
\text { batabilirsin, muhasebede de tam eşitliği sağladım derken bir hata } \\
\text { yüzünden başa dönebilirsin". "Ne giymem gerektiğini bilemiyorum, } \\
\text { muhasebenin de neresinden çalışmaya başlayacağımı bilemiyorum." }\end{array}$ \\
\hline \multirow[b]{2}{*}{ Yaz } & \multirow[b]{2}{*}{39} & Olumlu & 12 & “Her zaman canll ve eğlenceli." “Aydınlık ve bol güneşli.” \\
\hline & & Olumsuz & 27 & $\begin{array}{l}\text { "Hesaplar ve kodlar yaz gibi bunaltıcı." "Sıcak, boğucu, sıkıcı." "Çok } \\
\text { uğraştırır ve terletir, aynı yaz gibi." }\end{array}$ \\
\hline \multirow[b]{2}{*}{ Sonbahar } & \multirow[b]{2}{*}{83} & Olumlu & 0 & \\
\hline & & Olumsuz & 83 & $\begin{array}{l}\text { "Dersi anlayamadı̆̆ımdan hep bir hayal kırıklı̆̆ı.", "Iç karartıcı ve } \\
\text { hüzünlendirici”, "Yapraklar gibi ögrenciler de bu derste dökülür.", } \\
\text { "Sonbahar gibi çetin, karanlık ve kasvetli", "Hava bir açıyor bir } \\
\text { kapatıyor, muhasebede de bazı konular kolay bazıları zor.", "Bulutlu, } \\
\text { yağmurlu, karamsar, sıkıcı.", "Bir yanlış yaparsan mevsimi kışa } \\
\text { çevirir." }\end{array}$ \\
\hline \multirow[b]{2}{*}{$\mathrm{K}_{1}$ Ş } & \multirow[b]{2}{*}{87} & Olumlu & 13 & $\begin{array}{l}\text { "Her daim hareketli ve eğlenceli" "Ocak ayı yeni başlangıçlar } \\
\text { demektir, muhasebede de süreç o zaman başlar." "Nasıl kış mevsimi } \\
\text { olmazsa yaz kurak ve zorlu geçer, muhasebe iyi tutulmazsa da işletme } \\
\text { zora düşer." "Kış gibi soğk ve karmaşık görünür ama anlayınca } \\
\text { kolaydır." }\end{array}$ \\
\hline & & Olumsuz & 74 & $\begin{array}{l}\text { "Sınav sonuçlarl hep soğuk duş etkisi yapıyor, üşütüyor." "Soğuk, } \\
\text { karanlık, korkutucu ve hasta ediyor." "Zorlu klş şartlarında korunmak } \\
\text { gibi muhasebe de büyük emek ve fedakârlık ister." "Kış şartları insanı } \\
\text { yorar.", "Uzun ve yorucu." "Dlştan bakıldığında kar güzeldir, ama } \\
\text { içinde yaşamak zordur". }\end{array}$ \\
\hline \multirow{2}{*}{$\begin{array}{l}\text { İlişkisiz } \\
\text { Toplam } \\
\end{array}$} & 16 & & & \\
\hline & & & & 271 \\
\hline
\end{tabular}


Tablo 6'dan görüldüğü gibi, muhasebenin mevsim olarak metafor algılarında öğrencilerin en çok kullandıkları mevsimler kış ve sonbahardır. Kış benzetmesi yapan öğrencilerin çoğunluğu, muhasebeyi zorlu kış şartları gibi, yorucu, uzun, zor, soğuk, karanlık ve hasta edici bir ders olarak gördükleri için bu benzetmeyi yaptıklarını ifade etmişlerdir. Kış benzetmesini olumlu anlamda kullananlar ise, muhasebenin kış mevsimi gibi hareketli ve eğlenceli, yeni başlangıçları çağrıştıran ve işletme başarısı için önemli bir ders olduğuna vurgu yapmışlardır. Muhasebeyi sonbahara benzeten öğrencilerin tamamı bu benzetmeyi olumsuz anlamda kullanmışlar ve muhasebenin sonbahar gibi insana hayal kırıklığı ve hüzün duygusunu yaşatan, iç karartan, kasvetli, sıkıcı ve anlaşılmaz bir ders olduğunu söylemişlerdir.

Tablo 7. Katılımcıların Bir Oyun Türü Olarak Muhasebe Algıları

\begin{tabular}{|c|c|c|c|c|}
\hline Oyun Türü & \multicolumn{3}{|c|}{ f } & Çünkü \\
\hline \multirow[b]{2}{*}{ Bulmaca } & & Olumlu & 2 & "Kayıt alma süreci bulmaca çözmek gibi eğlenceli." \\
\hline & 12 & Olumsuz & 10 & $\begin{array}{l}\text { "Sonuca ulaşmak için çok fazla konu hakkında bilgi sahibi olmak } \\
\text { gerekir.", çözmesi zor ve karışı, yoğun düşünce faaliyeti gerektirir, } \\
\text { beyin yorar. "Hesaplar bulmaca gibi birbiriyle bağlantıll, biri } \\
\text { olmadan diğerini tamamlayamıyorsun." Neyi nereye yazacağımızı } \\
\text { (hangi hesabı kullanacağımızı) bilmek adeta bir bulmaca gibi.", }\end{array}$ \\
\hline \multirow[b]{2}{*}{ Futbol } & \multirow[b]{2}{*}{14} & Olumlu & 5 & $\begin{array}{l}\text { "Adeta bir takım oyunu, birbiriyle bağlantıll hesaplar doğru } \\
\text { kullanildığında gol olur.", "Eskimeyen ve taktiği ögrendiğin zaman } \\
\text { zevkli.", "Hak eden başarll olur.", "Terlersin, yorulursun ama gol } \\
\text { olduğunda her şeye değer." }\end{array}$ \\
\hline & & Olumsuz & 9 & $\begin{array}{l}\text { "Öğrenmek için hep pessinden kossmak gerekiyor.", "En ufak bir } \\
\text { hatada gol ofsayt karartyla iptal olabilir.", "Karmaşıl", }\end{array}$ \\
\hline \multirow[b]{2}{*}{ Puzzle/Yapboz } & \multirow[b]{2}{*}{15} & Olumlu & 5 & $\begin{array}{l}\text { "Gerekli parçalarl doğru yere koyarsan başarırsın.", "Muhasebe } \\
\text { konularl gibi parçalar birbirini tamamliyor." "Parçalarl } \\
\text { tamamlayınca bütünü görüyorsun." }\end{array}$ \\
\hline & & Olumsuz & 10 & $\begin{array}{l}\text { "Hangi hesabı nerede kullanacağını bulmak çok karışıı", Bir sürü } \\
\text { parça ve tamamlamak zor.", "Her konu birbiriyle alakal, bir tanesini } \\
\text { anlamayınca gerisi gelmiyor." }\end{array}$ \\
\hline \multirow[b]{2}{*}{ Saklambaç } & \multirow[b]{2}{*}{35} & Olumlu & 7 & $\begin{array}{l}\text { "Işletmenin bütün gizli bilgileri içinde sakll, işletmeler için çok } \\
\text { önemli", "Gizli olan her şeyi açığa çıarır, işletmede muhasebeden } \\
\text { gizli hiçbir şey yapılamaz." }\end{array}$ \\
\hline & & Olumsuz & 28 & $\begin{array}{l}\text { "Doğru cevapların bulunması zor.", "Hangi hesabı kullanacă̆ımızı } \\
\text { bilmiyorsak arar dururuz.", "Muhasebede doğru yolu bulamiyorum", } \\
\text { "Neyin nereden çıkacağı belli olmuyor.", "Ne kadar saklansan da o } \\
\text { seni bulur." }\end{array}$ \\
\hline \multirow[b]{2}{*}{ Sudoku } & \multirow[b]{2}{*}{14} & Olumlu & 4 & $\begin{array}{l}\text { "Çok zevkli, sudoku çözer gibi, rakamlarl doğru yerlere } \\
\text { yerlesstiriyoruz.", "çift tarafl kayutlart essitlemekle sudokudaki satır ve } \\
\text { sütunlart doldurmak birbirine benziyor, çok zevkli." }\end{array}$ \\
\hline & & Olumsuz & 10 & 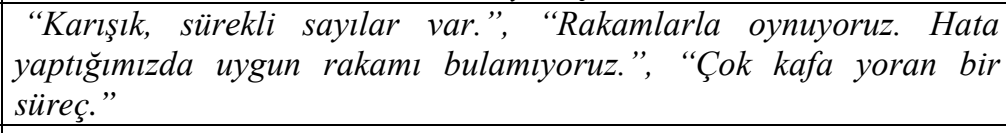 \\
\hline \multirow[b]{2}{*}{101} & \multirow[b]{2}{*}{8} & Olumlu & 0 & $*$ \\
\hline & & Olumsuz & 8 & $\begin{array}{l}\text { "Beyni yorarak hesaplama yaptırıyor.", "Zevkli değil.", "Karışık", } \\
\text { "Sayılarla çok uğraşıyoruz." }\end{array}$ \\
\hline \multirow[b]{2}{*}{ Jenga } & \multirow[b]{2}{*}{7} & Olumlu & 0 & \\
\hline & & Olumsuz & 7 & $\begin{array}{l}\text { "En baştan iyi oturtamazsan devamı gelmez." "en ufak bir hatada her } \\
\text { şey yerle bir olur.", "Çok dikkat gerektirir, yavaş hamlelerle hareket } \\
\text { edilmelidir." }\end{array}$ \\
\hline Monopoly & 9 & Olumlu & 8 & "Strateji çok önemlidir", "İçinde hem para var, hem de zevkli.", \\
\hline
\end{tabular}




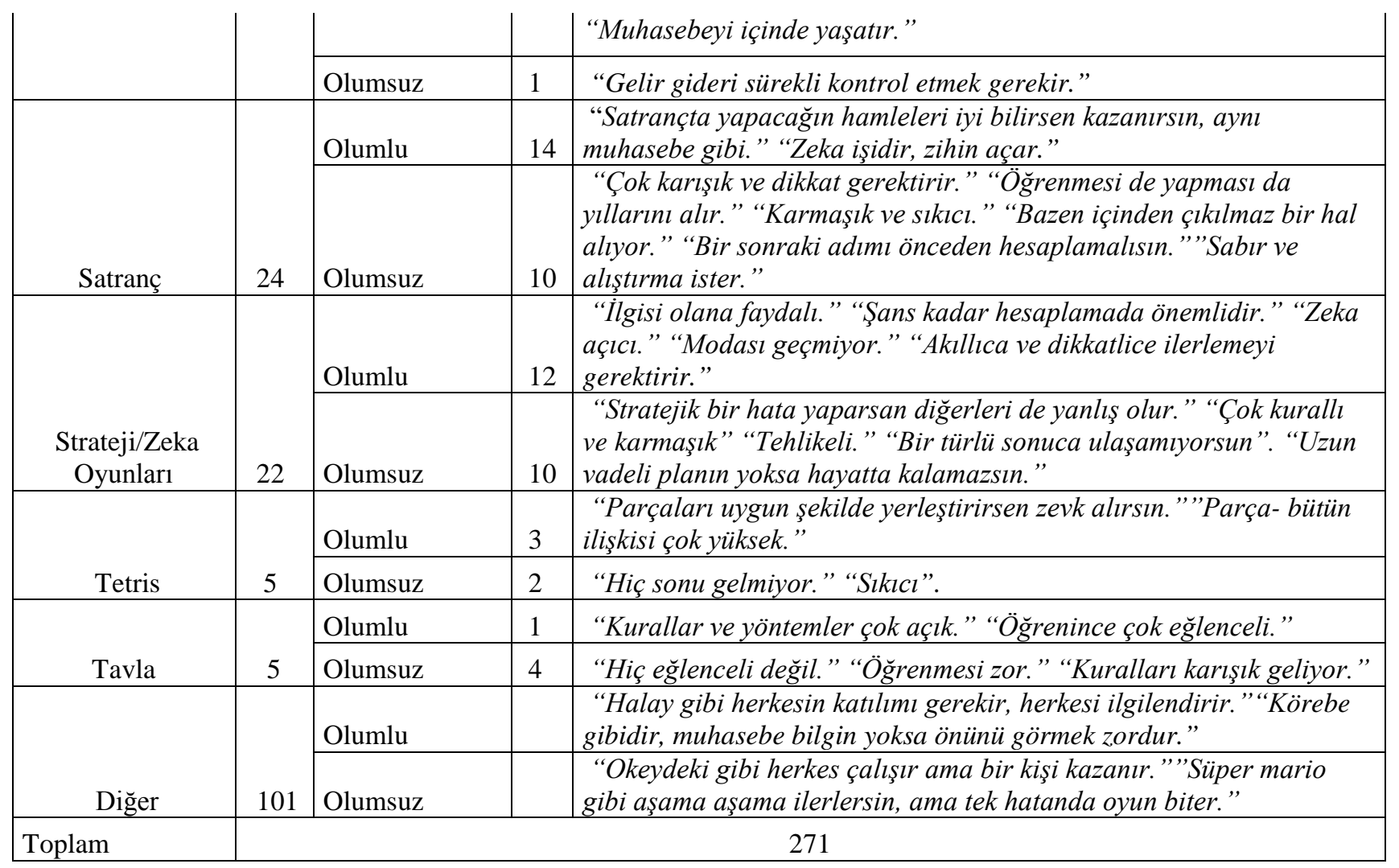

Tablo 7'de öğrencilerin bir oyun türü olarak muhasebeye ilişkin algılarını gösteren metaforlar görülmektedir. Çok çeşitli metaforlar içinde en sık kullanılan oyun türleri, saklambaç, satranç ve strateji/zeka oyunlarıdır. Saklambaç oyununu muhasebeye benzeten öğrencilerin çoğu, olumlu anlamda muhasebe gizli olan her şeyi açığa çıkarmada kullanıldığ için ve gizli bilgileri içinde barındırdığı için, olumsuz anlamda ise muhasebede doğru cevapların ve hangi hesapların kullanılacağının bulunmasının zor olması sebebiyle muhasebeyi saklambaç oyununa benzettiklerini dile getirmişlerdir. Satranç benzetmesini yapan öğrenciler ise, bu oyunu bir yandan zihinsel faaliyet, mantık yürütme ve zeka gerektiren; aynı zamanda karışık, sıkıcı, öğrenmesi zor ve sabır isteyen bir oyun olarak gördüklerinden bu benzetmeyi kullanmışlardır. Bazı öğrenciler ise, muhasebeyi, akıl ve dikkat gerektiren, zeka açan, kurallı, tehlikeli, strateji ve taktik gerektiren bir ders olarak gördüklerinden strateji/zeka oyunu benzetmesini kullanmışlardır.

Tablo 8. Katılımcıların Bir Çiçek Olarak Muhasebe Algıları

\begin{tabular}{|c|c|c|c|c|}
\hline Ciccek Türü & \multicolumn{3}{|l|}{ f } & Cünkü \\
\hline & & Olumlu & 53 & $\begin{array}{l}\text { "Dikenli ama güzel, seviyorsan katlanacaksın." , "Gülü seven } \\
\text { dikenine muhasebeyi seven bass ağrısına katlanır.", "Muhasebe de gül } \\
\text { gibi katman katman, dersi sevdim ve benim için gül gibi açıldl.", }\end{array}$ \\
\hline Gül & 62 & Olumsuz & 9 & $\begin{array}{l}\text { "Her güzel şeyin bir kusuru vardır, muhasebe de gerekli ama çok } \\
\text { zor.", "En küçük bir hatada dikenler eline batabilir.", "Muhasebe de } \\
\text { gül gibi ilgi ister, ilgi göstermezsen solar gider." }\end{array}$ \\
\hline Kaktüs & 64 & Olumlu & 9 & $\begin{array}{l}\text { "Eğer sağlam adımlar atarsanız, dikenleri size batmaz.", "Yoğun } \\
\text { sicak çöl ortaminda yetişen tek çiçek türü", "Dlşarıdan bakinca } \\
\text { karmașlk fakat içine girince oldukça yararl,", "Dikenleri actsa da }\end{array}$ \\
\hline
\end{tabular}




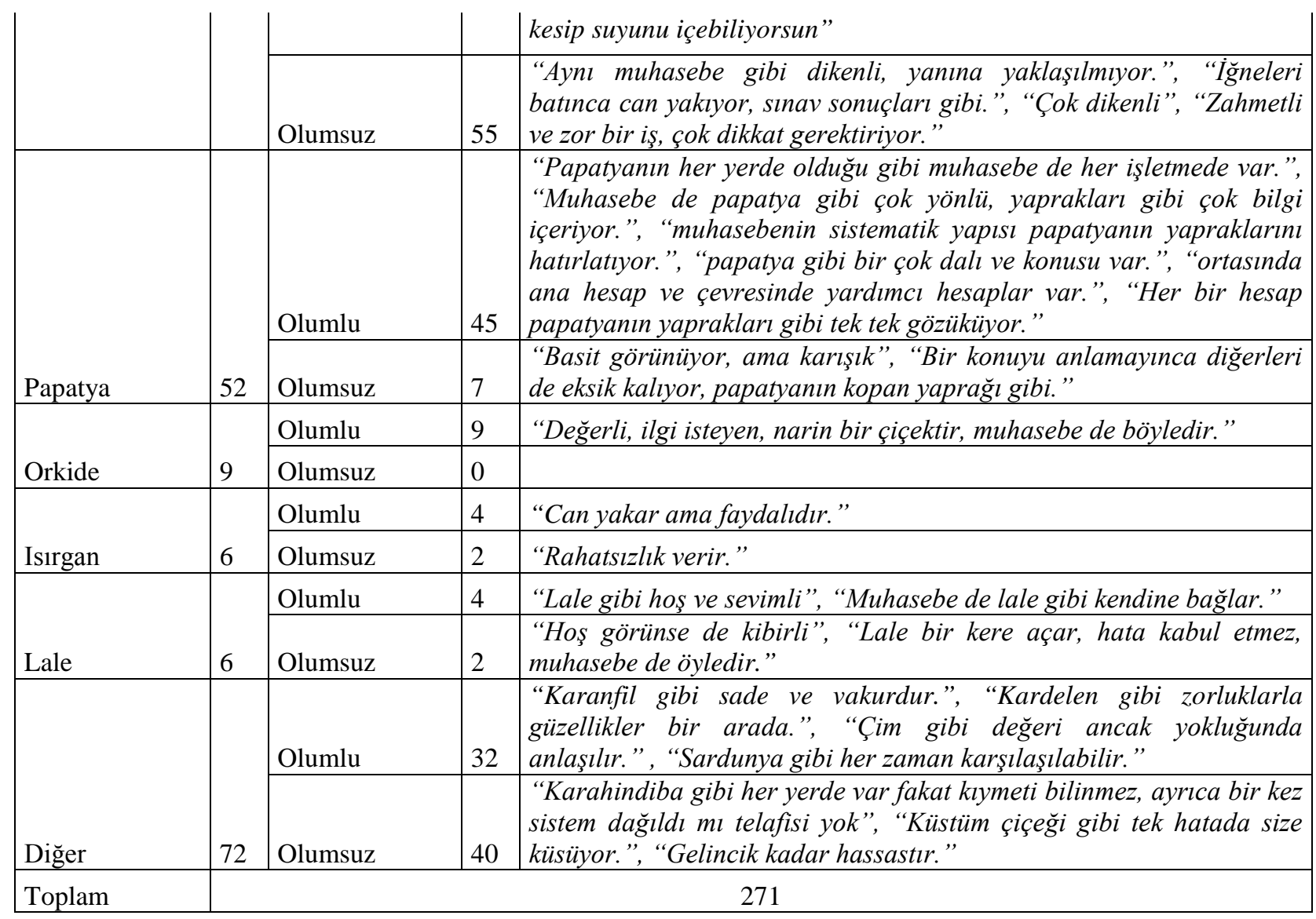

Tablo 8'de öğrencilerin muhasebenin çiçek olarak metafor algılarında gül, kaktüs ve papatyanın en çok kullandıkları çiçekler olduğu görülmektedir. Gül benzetmesini yapan öğrenciler, muhasebenin zor, dikkat gerektiren, hata kabul etmeyen ve özel ilgi isteyen yapısı sebebiyle bu benzetmeyi yapmışlar, bazı öğrenciler de gül katmanları gibi muhasebenin de aşama aşama birbirini tamamlayan konulardan oluştuğunu ifade etmiştir. Muhasebeyi kaktüse benzeten bazı öğrenciler, muhasebenin kaktüs gibi dikenli, can yakıcı, zahmetli ve zor bir ders olduğunu ifade etmiştir, ancak iyi çalışılırsa başarılı olunabileceğini ve fayda sağlayacağını söyleyen öğrenciler de olmuştur. Papatya benzetmesini yapanlar ise, papatya nasıl doğada her yerde yetişiyorsa, muhasebenin de her işletmede varlığı, çok yönlü ve papatya yaprakları gibi çok konu/dal içeren, karışık ve bilgi isteyen bir ders olması gerekçesiyle bu benzetmeyi yaptıklarını söylemişlerdir.

Tablo 9. Katılımcıların Bir Eşya Olarak Muhasebe Algıları

\begin{tabular}{|c|c|c|c|c|}
\hline Eşyalar & \multicolumn{3}{|c|}{$\mathbf{f}$} & Çünkü \\
\hline & & Olumlu & 18 & $\begin{array}{l}\text { "Tüm saylsal derslerde faydall, muhasebe de her alanda faydall" } \\
\text { "Hesap makinesi her türlü işlemi yapabilir, muhasebe de işletmedeki } \\
\text { tüm sorunlarl çözer" "Bize net sonuçlar verir, suistimale yer yoktur". } \\
\text { "Hesap makinesi gibi bize yardımcl" }\end{array}$ \\
\hline $\begin{array}{c}\text { Hesap } \\
\text { makinesi }\end{array}$ & 39 & Olumsuz & 21 & $\begin{array}{l}\text { "Hesap makinesi gibi mekanik ve tekrarlayıcı işlemlerden oluşur" } \\
\text { "Çok işlem gerekli, hesap makinesiz olmaz", "Tüm sayılart içeriyor, } \\
\text { sürekli hesap kitap var" "karmaşık" }\end{array}$ \\
\hline Defter & 12 & Olumlu & & \\
\hline
\end{tabular}




\begin{tabular}{|c|c|c|c|c|}
\hline & & Olumsuz & 12 & $\begin{array}{l}\text { "Sürekli birşeyleri kaydediyoruz." "Defter gibi taşımayı sevmiyorum } \\
\text { ama gerekli" }\end{array}$ \\
\hline \multirow[b]{2}{*}{ Buzdolabi } & \multirow[b]{2}{*}{7} & Olumlu & 4 & $\begin{array}{l}\text { "İçinde ihtiyacımız olan her tür gıdayı barındırlyor, muhasebede } \\
\text { yönetime gerekli her türlü bilgiyi bartndırır bünyesinde." "Gerekli ve } \\
\text { faydall". }\end{array}$ \\
\hline & & Olumsuz & 3 & "Buzdolabı gibi soğuk bir ders." \\
\hline \multirow[b]{2}{*}{ Ayna } & \multirow[b]{2}{*}{5} & Olumlu & 5 & "Herşeyi olduğu gibi gösterir, gizli hesaplamalar olamaz" \\
\hline & & Olumsuz & & \\
\hline \multirow[b]{2}{*}{ Kalem } & \multirow[b]{2}{*}{14} & Olumlu & 10 & $\begin{array}{l}\text { "Kalemsiz yazl, muhasebesiz işletme olmaz". "Bilgi aktarımında } \\
\text { yardımcl, muhasebe de öyle" }\end{array}$ \\
\hline & & Olumsuz & 4 & "Sürekli yazı yazmak, hesap tutmak gerekir". \\
\hline \multirow[b]{2}{*}{ Bilgisayar } & \multirow[b]{2}{*}{8} & Olumlu & 7 & $\begin{array}{l}\text { "Tüm verilerin kaydedildiği ve saklandiğ yer, muhasebe de işletme } \\
\text { bilgilerini kaydeder." "Bilgisayar birden fazla işlemi aynı anda } \\
\text { yürütür, muhasebede de birden fazla veri kullanılarak aynı anda farkll } \\
\text { analizler yapılabilir." }\end{array}$ \\
\hline & & Olumsuz & 1 & "Bilgisayar gibi karmaşık bir yapısı var". \\
\hline \multirow[b]{2}{*}{ Dolap } & \multirow[b]{2}{*}{7} & Olumlu & 5 & "Kendi içinde düzenli ve sistemli" "Tüm bilgileri içinde barındırır" "“ \\
\hline & & Olumsuz & 2 & "İçi çok dolu ancak hiçbir şey bulamıyorum" "Boşuna yer kaplyyor." \\
\hline \multirow[b]{2}{*}{ Masa } & \multirow[b]{2}{*}{11} & Olumlu & 6 & $\begin{array}{l}\text { "Etrafinda toplanilır, muhasebede de hesaplar bilançoda toplanır." } \\
\text { "Masa gibi düzenli olursak başarabiliriz" "Masa ayaklart gibi, } \\
\text { işletmeyi ayakta tutan da muhasebedir". }\end{array}$ \\
\hline & & Olumsuz & 5 & $\begin{array}{l}\text { "Sürekli çalışmak gerekir" "Üzerinde çok zaman geçirilir" "Masa } \\
\text { başı işidir, slkıcıdır" }\end{array}$ \\
\hline \multirow[b]{2}{*}{ Gözlük } & \multirow[b]{2}{*}{6} & Olumlu & 4 & $\begin{array}{l}\text { "Gözlük güneşten korur, iyi bir muhasebe de zarara uğramaktan" } \\
\text { "Daha net görmemizi sağlar, muhasebe de bize yol gösterir." }\end{array}$ \\
\hline & & Olumsuz & 2 & "Kullanmayı sevmiyorum". \\
\hline \multirow[b]{2}{*}{ Merdiven } & \multirow[b]{2}{*}{5} & Olumlu & 2 & "Işs hayatında yükseklere çıkarabilecek bir derstir". \\
\hline & & Olumsuz & 3 & $\begin{array}{l}\text { "İlk basamakta zorlanmazsınız ama zirveye çıkmak için çok efor } \\
\text { gereklidir". "Merdiven basamakları gibi tek bir konu kaçırmadan } \\
\text { çalışılması gereken bir ders." "Hızla tırmanmana yardımcı olduğu } \\
\text { gibi tek bir yanlıșta kendini aşağıda bulabilirsin." }\end{array}$ \\
\hline \multirow[b]{2}{*}{ Saat } & \multirow[b]{2}{*}{7} & Olumlu & 4 & $\begin{array}{l}\text { "Birbirini tamamlayan çarklar, aynı muhasebe konuları gibi". } \\
\text { "Muhasebe dede zamanlama çok önemli". }\end{array}$ \\
\hline & & Olumsuz & 3 & "Sürekli işliyor, çok yorucu”." Karmaşık bir mekanizması var." \\
\hline \multirow[b]{2}{*}{ Kasa } & \multirow[b]{2}{*}{5} & Olumlu & 5 & $\begin{array}{l}\text { "100-kasa olmadan muhasebe de olmaz". "Parayla ilgili". } \\
\text { "Paralarımızı güvende tutar." }\end{array}$ \\
\hline & & Olumsuz & & \\
\hline \multirow[b]{2}{*}{ Televizyon } & \multirow[b]{2}{*}{5} & Olumlu & 3 & "Şirketin mali durumunu muhasebe sayesinde izleyebilirsin" \\
\hline & & Olumsuz & 2 & $\begin{array}{l}\text { "Çok fazla izlersen gözü ve beyni yorar". "Sürekli yeni gelişmeleri } \\
\text { takip etmek gerekir". }\end{array}$ \\
\hline \multirow[b]{2}{*}{ Diğer } & \multirow[b]{2}{*}{140} & Olumlu & 35 & $\begin{array}{l}\text { "Kitap gibi bize birşeyler öğretir". "Kamera gibi herşey kayıt altına } \\
\text { alınır,objektiftir." "Tarak saçlarl, muhasebe hesapları düzenler" } \\
\text { "Matruşka gibi hesaplar içiçedir". "Terazi gibi sürekli denge vardır" } \\
\text { "Gaz lambast gibi meşakkatli ama aydınlı̆̆a kavuşturur" "Bulaşık } \\
\text { makinesi gibi gerekli ve hayatı kolaylaştırır." "Muhasebe işletmede } \\
\text { başarının anahtarıdır". }\end{array}$ \\
\hline & & Olumsuz & 105 & 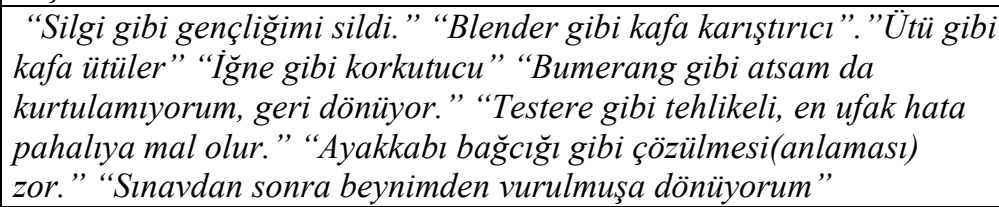 \\
\hline Toplam & & & & 271 \\
\hline
\end{tabular}


Tablo 9'a göre, öğrencilerin bir eşya olarak muhasebe algıları için en sık kullandıkları metaforlar, hesap makinesi, kalem ve defterdir. Öğrencilerin bazıları muhasebenin hesap makinesi gibi faydalı, yardımcı, tüm işlemleri yaparak sorunları çözen, net sonuçlar veren bir ders olduğunu ifade etmişlerdir. Bazıları ise hesap makinesi benzetmesini olumsuz anlamda kullanarak, muhasebenin hesap makinesi gibi karmaşık, çok işlem gerektiren, mekanik ve tekrarlayıcı işlemlerden oluşan bir ders olduğunu söylemişlerdir. Kalem benzetmesi yapan öğrenciler muhasebenin kalem gibi bilgi aktarmada yardımcı ve gerekli olduğunu, defter benzetmesi yapan öğrenciler ise muhasebede yoğun şekilde kayıt işlemlerinden oluştuğunu düşünerek bu benzetmeleri yaptıklarını söylemişlerdir.

Muhasebe eğitimi alan öğrencilerin, yedi metafor başlığından faydalanılarak oluşturulan muhasebe kavramına ilişkin algıları toplam 9 kategori altında toplanmıştır. Öğrenciler tarafından üretilen metaforların ait oldukları kavramsal kategoriler frekanslarıyla birlikte aşağıda Tablo 10'da sunulmaktadır.

Tablo 10: Katılımcıların Muhasebeye İlişkin Metaforlarından Oluşturulan Kavramsal Kategoriler

\begin{tabular}{|l|l|l|l|l|l|l|l|l|}
\hline Kavramsal Kategoriler & Renk & Hayvan & $\begin{array}{l}\text { Besin } \\
\text { Türü }\end{array}$ & Mevsim & Oyun & Çiçek & Eşya & Toplam \\
\hline $\begin{array}{l}\text { Heyecan verici bir ders olarak } \\
\text { muhasebe }\end{array}$ & 7 & 3 & 15 & 37 & 19 & 54 & 8 & 143 \\
\hline $\begin{array}{l}\text { Zor, Sıkıc, Karmaşık bir ders } \\
\text { olarak muhasebe }\end{array}$ & 63 & 55 & 77 & 152 & 48 & 94 & 25 & 484 \\
\hline $\begin{array}{l}\text { Kurallı, düzenli ve sistematik bir } \\
\text { ders olarak muhasebe }\end{array}$ & 21 & 18 & 2 & 4 & 27 & 9 & 25 & 106 \\
\hline $\begin{array}{l}\text { Diğer bilim dallarılyla ilişkili bir } \\
\text { ders olarak muhasebe }\end{array}$ & 4 & & 8 & 1 & 36 & 11 & 5 & 65 \\
\hline $\begin{array}{l}\text { Yol gösterici bir ders olarak } \\
\text { muhasebe }\end{array}$ & 10 & 2 & & & 2 & 1 & 43 & 58 \\
\hline $\begin{array}{l}\text { Dikkat ve çok çalışma gerektiren } \\
\text { bir ders olarak muhasebe }\end{array}$ & 14 & 34 & 8 & 7 & 12 & 28 & 6 & 109 \\
\hline $\begin{array}{l}\text { Zeka gerektiren bir ders olarak } \\
\text { muhasebe }\end{array}$ & 1 & 23 & 4 & & 50 & 5 & 27 & 110 \\
\hline $\begin{array}{l}\text { Gerekli, faydalı ve önemli bir ders } \\
\text { olarak muhasebe }\end{array}$ & 3 & 37 & 101 & 7 & 11 & 21 & 10 & 190 \\
\hline $\begin{array}{l}\text { Parayla ilişkili bir ders olarak } \\
\text { muhasebe }\end{array}$ & 8 & & 2 & 1 & 5 & 2 & 6 & 24 \\
\hline
\end{tabular}

Tablo 10'da görüldüğü gibi muhasebe eğitimi alan öğrencilerin muhasebeye ilişkin en fazla metaforun üretildiği kategoriler "zor, sıkıcı ve karmaşık bir ders olarak muhasebe", "gerekli, faydalı, önemli bir ders olarak muhasebe" ve "heyecan verici bir ders olarak muhasebe” kategorileridir. Yine tabloya göre, öğrencilerin renk, hayvan, mevsim ve çiçek metaforunda, muhasebenin zor, sıkıcı ve karmaşık olması, besin türü metaforunda gerekli, faydalı ve önemli olması, oyun türü metaforunda zeka gerektiren bir ders olması, eşya metaforunda yol gösterici olması yönlerini ön plana çıkardıkları görülmektedir. 


\section{SONUÇ}

Çalışmanın amacı, muhasebe eğitimi alan öğrencilerin muhasebe kavramına ilişkin sahip oldukları duygu ve düşünceleri, renk, hayvan, besin türü, mevsim, oyun, çiçek ve eşya metaforları aracılığıyla ortaya çıkarmaktır.

$\mathrm{Bu}$ amaç doğrultusunda yapılan çalışmada öğrenciler tarafından her bir metafor başlığ1 için en sık kullanılan metaforlar sırayla "siyah, aslan (kaplan), sebze türü, kış, saklambaç, kaktüs ve hesap makinesi" dir. Yedi metafor başlığından faydalanılarak oluşturulan muhasebe kavramına ilişkin öğrenci algıları toplam 9 kategori altında toplanmıştır. Muhasebe kavramının değişik yönlerine vurgu yapan metaforların ortak özellikleri dikkate alınarak oluşturulan bu kategoriler, sırasıyla "Heyecan verici bir ders olarak muhasebe”, “ Zor, sıkıcı, karmaşık bir ders olarak muhasebe" "Kurallı, düzenli ve sistematik bir ders olarak muhasebe", "Diğer bilim dallarıyla ilişkili bir ders olarak muhasebe", "Yol gösterici bir ders olarak muhasebe", "Dikkat ve çok çalışma gerektiren bir ders olarak muhasebe", "Zeka gerektiren bir ders olarak muhasebe", "Gerekli, faydalı ve önemli bir ders olarak muhasebe" "Parayla ilişkili bir ders olarak muhasebe" olarak belirlenmiştir. Bu kategoriler içinde en fazla metaforun üretildiği kategori "Zor, sıkıcı, karmaşık bir ders olarak muhasebe" (484), en az metaforu içeren ise, "parayla ilişkili ders olarak muhasebe" (24) kategorisidir. Bazı metaforların ise birden fazla kategori altında yer alabildiği görülmüştür.

Yine çalışmada, öğrencilerin renk, hayvan, mevsim ve çiçek metaforları ile muhasebenin "zor, sıkıcı ve karmaşık bir ders olma", besin türünde "gerekli, faydalı ve önemli bir ders olma", oyunda "zeka gerektiren bir ders olma" ve eşya metaforunda ise "kurallı, düzenli ve sistematik bir ders olma" yönlerini öne çıkardıkları görülmektedir. Ayrıca öğrenciler tarafindan tercih edilen metaforların daha çok olumsuz anlam taşıdıkları görülmüştür. Yani öğrenciler bir olgu olarak muhasebeyi negatif yönlü algılamaktadır. Öğrencilerin muhasebe mesleği ve dersine ilişkin verdikleri cevaplar da elde edilen sonucu desteklemektedir. Zira, anketin ilk kısmındaki verilere bakıldığında öğrencilerin yalnızca \%23.6' sının mezuniyet sonrası muhasebe mesleğini seçmeyi düşündüğü ve sadece \%7.4' ünün muhasebe mesleğine yüksek derecede ilgi duyduğu görülmektedir.

Öğrencilerin muhasebeye ilişkin olumsuz algılarının nedenlerinden bazıları, ilk kez karşılaştıkları muhasebe dersinin işleyiş sisteminin karışık gelmesi, muhasebenin kurallara dayalı olması, konuların kapsamlı olması ve öğrencilerin daha önceki öğrenimleri sebebiyle (borç-alacak kavramı gibi) kavram yanılgısına sahip olması olabilir. Muhasebeye ilişkin oluşan bu olumsuz algıların değiştirilmesi, muhasebe eğitiminin daha ilgi çekici hale getirilmesi ve muhasebe meslek imajının olumlu yönde artırılması adına, muhasebenin işletmedeki önemi, rolü ve muhasebe elemanının bu süreçteki görev ve sorumluluklarının belirgin şekilde öğretim elemanları tarafından öğrencilere anlatılmasının önemli olduğu düşünülmektedir. Bu sayede sadece sınava ve dersi geçmeye dayalı olmayan ve muhasebenin öğrenci gözündeki değerini artırıcı öğretim metotları ve ders içerikleri ile öğrencilerin dört yıllık ögrrenim sürecinde muhasebeye olan ilgi ve motivasyonlarının artırılması mümkün olabilecektir.

Muhasebe eğitiminde anlamlı ve kalıcı öğrenme oluşabilmesi için diğer pek çok faktörün yanında öğrencilerin derse ilişkin öğrenme istek ve heyecanının artırılması çok önemlidir. Öğrencilerin muhasebe dersine ilişkin geliştirmiş oldukları metaforlar, onların 
ilerde aktif iş hayatında potansiyel meslek olarak seçebilecekleri muhasebe mesleğine olan bakış açılarını açıklama ve anlamada önemli bir veri kaynağıdır. Öğrencilerin muhasebe eğitiminin temelinin atıldığı genel muhasebe dersine ilişkin algıları, ileriki sınıflarda görecekleri diğer muhasebe derslerine olan bakış açılarını ve yine ileride bir meslek seçeneği olarak karşılarına çıkacak olan muhasebe meslek mensubu olma algılarını da etkileyeceğinden konunun önemi artmaktadır. Bu noktada, lisans öğreniminin ileriki yıllarındaki muhasebe öğrenimine yönelik olumlu tutum oluşturacak etkinliklere yer verilmesi gerekmektedir. $\mathrm{Bu}$ doğrultuda muhasebe öğretim elemanı, öğrenci, muhasebe meslek mensubu ve işletme yöneticileri gibi muhasebe eğitiminde yer alan paydaşların algılarına yönelik yapılacak çalışmaların TÜRMOB ve diğer meslek kuruluşları ile üniversite yönetimi tarafından dikkate alınarak gerekli düzenlemelerin yapılması ile muhasebeye yönelik algıların daha olumlu hale getirilmesi sağlanabilir.

Gelecek çalışmalarda, muhasebe öğretim elemanlarından muhasebe kavramına ilişkin metaforlar üretmeleri istenebilir. Toplumda değişik statülerdeki kişilere muhasebe mesleği hakkındaki metaforik düşünceleri sorularak muhasebe elemanlarının sosyal statüleri, imajı ve nasıl algılandığına ilişkin bilgiler toplanabilir. Yine, öğrencilerin muhasebeye ilişkin algıları farklı yıllarda ölçülerek, herhangi bir değişim olup olmadığı ortaya konabilir.

\section{KAYNAKLAR}

Ağca, Ahmet - Zeytinoğlu, Emin (2008), "Mevcut Muhasebe Eğitimi Değişmeli mi?Öğrencilerin Muhasebe Mesleğine Karşı Tutumları Üzerine Bir Araştırma”, XXVII.Türkiye Muhasebe Eğitimi Sempozyumu-, 23-27 Nisan, Antalya, ss. 3-26.

Arslan, M.Metin-Bayrakçı, Mustafa (2006), "Metaforik Düşünme ve Öğrenme Yaklaşımının Eğitim-Öğretim Açısından İncelenmesi”, Milli Eğitim Dergisi, Y1l 35, Sayı 171, ss. 100-108.

Aslan, Gülay (2015), “Öğretmen Adaylarının Toplumsal Cinsiyet Algılarına İlişkin Metaforik Bir Çözümleme”, Eğitim ve Bilim, Cilt 40, Sayı 181, ss.363-384.

Ateş, Murat- Karatepe, Akif (2013), “Üniversite Öğrencilerinin “Çevre”Kavramına İlişkin Algılarının Metaforlar Yardımıyla Analizi”, International Journal of Social Science, 6(2), pp.1327-1348.

Aygün, Davut- Gerekan, Bilal (2012), “ Muhasebe Dersini İlk Defa Alan Öğrencilerin Derse Yönelik Algılarının Tespiti: Karşılaştırmalı Bir Alan Araştırması”, Yönetim ve Ekonomi Araştırmaları Dergisi, Sayı 18,ss. 48-63.

Ayyıldız, Tebessüm (2016), "Üniversite Öğrencilerinin Dans Kavramına Yönelik Metaforik Algılarının Analizi”, Gazi Üniversitesi Spor Bilimleri Dergisi, Cilt 1, Sayı 2, Aralık, ss. $13-25$.

Başarır, Fatma- Sarı, Mediha (2015), "Kadın Akademisyenlerin "Kadın Akademisyen Olma”ya İlişkin Algılarının Metaforlar Yoluyla İncelenmesi”, Yükseköğretim ve Bilim Dergisi, Cilt 5, Sayı 1, Nisan, ss. 41-51. 
Cansever, Belgin Arslan- Aslan, Neşe (2016), “Teacher” From The Children's Perspective: A Study By Metaphors”, Journal of Education and Learning, Vol 5, No 4, pp. 21-36.

Cerit, Yusuf (2008), “Öğretmen Kavramı ile İlgili Metaforlara İlişkin Öğrenci, Öğretmen ve Müdürlerin Görüşleri”, Türk Eğitim Bilimleri Dergisi, Cilt6, Sayı 4, ss. 693-712.

Demirci Güler, Mutlu Pınar (2012), "Sınıf Öğretmeni Adaylarının Fen ve Teknoloji Dersine İlişkin Metaforik Tanımlamaları”, Elektronik Sosyal Bilimler Dergisi, Cilt 11, Sayı1, ss. $53-63$.

Demirel Utku, Burcu- Erol, İbrahim (2015), "Lisans Öğrencilerinin Muhasebeye Giriş Dersine Yönelik Algılamalarının Belirlenmesi”, Journal of Accounting, Finance and Auditing Studies, 1(3), ss. 91-104.

Demirtaş Hasan- Çoban, Duygu (2014a), "Üniversite Öğrencilerinin, Üniversite ve Fakülte Kavramlarına İlişkin Metaforları (İnönü Üniversitesi Örneği)", Ondokuz Mayıs Üniversitesi Eğitim Fakültesi Dergisi, Cilt 33, Sayı 1, ss. 113-143.

Demirtaş Hasan- Çoban, Duygu (2014b), “ Üniversite Öğrencilerinin Öğretim Elemanlarına İlişkin Metaforları”, Kastamonu Üniversitesi Kastamonu Eğitim Dergisi, Cilt 22, Sayı 3, ss. 1279- 1300 .

Doğan, Yakup (2017), “Ortaokul Öğrencilerinin Çevre Kavramına İlişkin Sezgisel Algıları: Bir Metafor Analizi”, Ahi Evran Üniversitesi Kırşehir Eğitim Fakültesi Dergisi (KEFAD), Cilt 18, Say1 1, Nisan ss. 721-740.

Erol, İbrahim - Demirel Utku, Burcu (2015), "Finansal Muhasebe Dersinde Öğrencilerde Oluşan Kavram Yanılgılarının İncelenmesi”, İnternational Journal of Social Sciences and Education Research, 1(4), ss. 1307-1319.

Ertaş, Fatih Coşkun-Erdem, Meziyet Sema (2008), "Muhasebe Derslerinde Öğrenci Başarılarını Etkileyen Faktörler", XXVII.Türkiye Muhasebe Eğitimi SempozyumuBilgi Çağında Muhasebe Eğitimi, 23-27 Nisan, Antalya, ss. 63-86.

Ertuğrul, İrfan- Özdemir, Serkan (2014), "Muhasebe Dersi Alan Ön lisans ve Lisans Öğrencilerinin Derse Yönelik Tutumlarının Tespiti: Ege Bölgesinde Bir Uygulama”, Niğde Üniversitesi İktisadi ve İdari Bilimler Fakültesi Dergisi, Cilt 7, Sayı 1, ss. 204214.

Geiger, Marshall A.-Ogilby, Suzanne M. (2000), “The First Course In Accounting: Students’ Perceptions And Their Effect On The Decision To Major In Accounting”, Journal of Accounting Education, 18 (2), pp. 63 - 78.

Gökgöz, Ahmet - Dizkırıcı, Ahmet Selçuk (2013), "How is Accounting Perceived in Cognitive Level? A Study Based On Metaphor", International Journal of Education and Research, Vol 1, No 7, July, pp. 1-6. 
Gökgöz, Ahmet (2012), "Determination Of Perceptions About Accountants Through Metaphors:A Case Of Turkey”, Interdisciplinary Journal Of Contemporary Research In Business, Vol 4, No 2, June, pp. 62-71.

Güler, Mürsel- Ağca, Ahmet -Boz, Dursun (2016), “İşletme Öğrencilerinin Muhasebe Algilarının Metaforlar Yardımıyla Anlatılması", PressAcademia Procedia, Vol 2, ss. 298-309.

Güveli, Ebru- İpek, A. Sabri- Atasoy, Ercan- Güveli, Hasan (2011), "Sınıf Öğretmeni Adaylarının Matematik Kavramına Yönelik Metafor Algıları", Turkish Journal of Computer and Mathematics Education, Vol 2, No 2, ss. 140-159.

Güven, Bülent - Güven, Sibel (2009), “İlköğretim Öğrencilerinin Sosyal Bilgiler Dersinde Metafor Oluşturma Becerilerine İlişkin Nicel Bir Araştırma", Kastamonu Eğitim Dergisi, Cilt 17, No 2, ss. 503-512.

Hacıfazlığlu, Özge- Karadeniz Şirin- Dalgıç Gülay (2011), “Okul Yöneticilerinin Teknoloji Liderliğine İlişkin Algıları: Metafor Analizi Örneği”, Eğitim Bilimleri Araştırmaları Dergisi, Cilt 1, Sayı 1, ss. 97-121.

Jones, Jefferson. P. - Fields, Kent. T. (2001), “The Role Of Supplemental Instruction In The First Accounting Course”, Issues in Accounting Education, Vol 16, Issue 4, pp. 531547.

Karaçam Sedat-Aydın, Fatih (2014), “Ortaokul Öğrencilerinin Teknoloji Kavramına İlişkin Algılarının Metafor Analizi”, Gaziantep University Journal of Social Sciences, 13(2), ss. 545- 572.

Kesen, Aynur (2010), “Turkish EFL Learners’ Metaphors with Respect to English Language Coursebooks”, Novitas-ROYAL (Research on Youth and Language), 4 (1), pp. 108118.

Köse, Tunç - Gürbüz, Hüseyin (2009), “Muhasebeye Giriş Dersine İlişkin Görüşleri Belirlemeye Yönelik Bir Araştırma: Eskişehir Osman Gazi Üniversitesi İ.İ.B.F Örneği”, Muhasebe Bilim Dünyası Dergisi, Cilt 11, Sayı 4, ss. 107-146.

Mertol, Hüseyin- Doğdu, Mustafa- Yılar, Bayram (2013), "Üstün Zekâlı ve Yetenekli Öğrencilerin Sosyal Bilgiler Dersine İlişkin Metaforik Algıları", Üstün Yetenekliler Eğitimi Araştırmaları Dergisi (UYAD), 1(3), ss. 176-183.

Miles, Matthew. B. - Huberman, A. Michael (1994), Qualitative data analysis, Thousand Oaks, CA: Sage Publications, London.

Miller, Steven (1987), "Some Comments On The Utility Of Metaphors For Educational Theory And Practice”, Educational Theory,Vol 37,No 3, pp. 219-227 (Aktaran Davut Soysal -Özlem Afacan, İlköğretim Öğrencilerinin "Fen ve Teknoloji Dersi" ve "Fen ve Teknoloji Öğretmeni” Kavramlarına Yönelik Metafor Durumları, Mustafa Kemal Üniversitesi Sosyal Bilimler Enstitüsü Dergisi, Cilt 9, Sayı 19, ss.287-306.) 
Nalçacı, Ahmet- Bektaş, Fatih (2012), “Öğretmen Adaylarının Okul Kavramına İlişkin Algıları”, Ahi Evran Üniversitesi Kırşehir Eğitim Fakültesi Dergisi, Cilt 13, Sayı 1, Nisan, ss. 239-258.

Ocak, Gürbüz - Gündüz, Mevlüt (2006), “ Eğitim Fakültesini Yeni Kazanan Öğretmen Adaylarının Öğretmenlik Mesleğine Giriş Dersini Almadan Önce ve Aldıktan Sonra Öğretmenlik Mesleği Hakkındaki Metaforlarının Karşılaştırılması, Afyon Kocatepe Üniversitesi Sosyal Bilimler Dergisi, Cilt 8, Sayı 2, ss. 293-310.

Onay, Meltem-Ergüden, Sevinç (2012), "Yeni Bir Metafor: Kurum DNA's1”, Sosyal ve Beşeri Bilimler Dergisi, Cilt 4, No 1, ss.203-212.

Özbek, Yiğit (2015), "Farklı Eğitim Programlarındaki Öğrencilerin Genel Muhasebe Dersine İlişkin Algıları”, Eğitim ve Öğretim Araştırmaları Dergisi, Journal of Research in Education and Teaching, Mayıs, Cilt 4, Sayı 2 , ss. 24-34.

Özcan, İrfan- Ünal, Ferhan- Helhel, Yeşim (2009), "Muhasebe Programı Öğrencilerinin Cinsiyet ve Öğretim Durumunun Muhasebe Mesleğine Yönelik Tutumları İle İlişkilendirilmesi”, Muhasebe ve Finansman Dergisi, Say1 41, Ocak, ss. 170-181.

Saban, Ahmet (2008), “ Primary School Teachers’ and Their Students’ Mental Images about the Concept of Knowledge”, Elementary Education Online, 7(2), 421-455.

Saban, Ahmet (2009), “ Öğretmen Adaylarının Öğrenci Kavramına İlişkin Sahip Oldukları Zihinsel İmgeler”, Türk Eğitim Bilimleri Dergisi, Cilt 7, Sayı 2, ss.281-326.

Saçılık Yıldırım, Melahat- Çevik, Samet- Özkan, Çiğdem (2016), "Turizm ve Otel İşletmeciliği Bölümü Önlisans Öğrencilerinin “Turizm”Olgusuna İlişkin Metaforik Algıları”, Akademik Bakış Dergisi, Sayı:53, Ocak-Şubat, ss. 84-103.

Semerci, Çetin (2007), "Program Geliştirme Kavramına İlişkin Metaforlarla Yeni İlköğretim Programlarına Farklı Bir Bakış”. Cumhuriyet Üniversitesi Sosyal Bilimler Dergisi, Cilt 31, No 2, ss. 125-140.

Soysal, Davut- Afacan, Özlem (2012), "İlköğretim Öğrencilerinin "Fen ve Teknoloji Dersi" ve "Fen ve Teknoloji Öğretmeni" Kavramlarına Yönelik Metafor Durumları", Mustafa Kemal Üniversitesi Sosyal Bilimler Enstitüsü Dergisi, Cilt 9, Sayı 19, ss.287-306.

Taşdemir, Mehmet - Taşdemir, Figen (2016), "Öğretmen Adaylarının Bilimsel Araştırma Kavramına Yükledikleri Metaforlar”, Ahi Evran Üniversitesi Kırşehir Eğitim Fakültesi Dergisi (KEFAD), Cilt 17, Sayı 1, Nisan 2016, ss. 419-438.

Tortop, Hasan Said (2013), “Öğretmen Adaylarının Üniversite Hocası Hakkındaki Metaforları Ve Bir Değerlendirme Aracı Olarak Metafor”, Yükseköğretim ve Bilim Dergisi, Cilt 3, Say1 2, ss. 153-160.

Uçma, Tuba, (2010) “Kavramsal Metafor Olarak Muhasebeyi Anlamak”, Muhasebe ve Bilim Dünyas1 Dergisi, Cilt: 12, Say1 2, Haziran, ss. 123 - 141. 
Uysal, Özgür Özmen (2001), “Muhasebe Metinlerinde Metafor”, Ege Akademik Bakış Dergisi, 1(2), ss.53-60.

Walters York, L.Melissa (1996), “Metaphor in Accounting Discourse”, Accounting, Auditing \& Accountability Journal, Vol 9, Issue 5, pp. 45-70

Yalçın, Mikail- Özoğlu, Elif Aydoğdu - Dönmez, Ayşe (2016), “Öğretim Elemanlarının Araştırma Görevlisi Kavramına İlişskin Metaforik Algıları, Eğitim ve Bilim, Cilt 41, Say1 185, ss. 19-32.

Yıldırım, Suat (2015), “Genel Muhasebe Dersi Alan Öğrencilerin Derse İlişskin Beklentileri ve Başarı Durumlarının Değerlendirilmesi”, Muhasebe ve Denetime Bakış, Yıl 14, Say1 44, Ocak, ss. 1-15.

Yob, Iris .M. (2003), “Thinking Constructively With Metaphors”, Studies In Philosophy And Education, Vol 22, Issue 2, 127-138 (Aktaran Gürbüz Ocak- Mevlüt Gündüz, Eğitim Fakültesini Yeni Kazanan Öğretmen Adaylarının Öğretmenlik Mesleğine Giriş Dersini Almadan Önce ve Aldıktan Sonra Öğretmenlik Mesleği Hakkındaki Metaforlarının Karşılaştırılması, Afyon Kocatepe Üniversitesi Sosyal Bilimler Dergisi, Cilt 8, Sayı 2, 2006, ss. 293-310.) 